\title{
Genetic variation and evolution in the genus Apodemus (Muridae: Rodentia)
}

\author{
MARIA GRAZIA FILIPPUCCI ${ }^{1}$, MILOŠ MACHOLÁN ${ }^{2 *}$ and JOHAN R. MICHAUX ${ }^{3}$ \\ ${ }^{1}$ Department of Biology, University of Rome 'Tor Vergata', Via della Ricerca Scientifica, \\ I-00133 Rome, Italy \\ ${ }^{2}$ Institute of Animal Physiology and Genetics, Academy of Sciences of the Czech Republic, \\ Veveři 97, CZ-60200 Brno, Czech Republic \\ ${ }^{3}$ Laboratory of Palaeontology, Institut des Sciences de l'Evolution de Montpellier (UMR 5554), \\ University of Montpellier II, Place E. Bataillon, F-34095 Montpellier Cedex 05, France
}

Received June 2001; accepted for publication November 2001

\begin{abstract}
Genetic variation was studied using protein electrophoresis of 28-38 gene loci in 1347 specimens of Apodemus agrarius, A. peninsulae, A. flavicollis, A. sylvaticus, A. alpicola, A. uralensis, A. cf. hyrcanicus, A. hermonensis, A. $m$. mystacinus and $A$. m. epimelas, representing 121 populations from Europe, the Middle East, and North Africa. Mean values of heterozygosity per locus for each species ranged from 0.02 to 0.04 . Mean values of Nei's genetic distance $(D)$ between the taxa ranged from 0.06 (between $A$. flavicollis and A. alpicola) to 1.34 (between $A$. uralensis and A. agrarius). The highest values of $D$ were found between $A$. agrarius and other Apodemus species (0.62-1.34). These values correspond to those generally observed between genera in small mammals. Our data show that $A$. agrarius and $A$. peninsulae are sister species, well-differentiated from other taxa. High genetic distance between $A$. $m$. $m y s t a c-$ inus and A. m. epimelas leads us to consider them distinct species and sister taxa to other Western Palaearctic species of the subgenus Sylvaemus. The data also suggest a recent separation of members of the latter group from a common ancestor, and subsequent rapid radiation, making it difficult to infer phylogenetic relationships. Some taxonomic implications of the results are discussed further. (C) 2002 The Linnean Society of London, Biological Journal of the Linnean Society, 2002, 75, 395-419.
\end{abstract}

ADDITIONAL KEYWORDS: electrophoresis - genetic differentiation - Palaearctic region - phylogeny Sylvaemus - wood mice.

\section{INTRODUCTION}

Wood mice of the genus Apodemus Kaup, 1829 are widespread in temperate areas of the Palaearctic region. Traditionally, the genus has been subdivided according to Zimmermann (1962) into three subgenera: Apodemus, known from central Europe to eastern Asia, western Palaearctic Sylvaemus, and Eastern Palaearctic Alsomys (see Musser \& Carleton, 1993 for a general review). Recently, however, Musser et al. (1996), focusing on the Apodemus-Sylvaemus systematic problem, have separated wood mice into three groups: Sylvaemus (A. sylvaticus, A. flavicollis, A.

*Corresponding author. E-mail address: macholan@iach.cz uralensis, A. mystacinus, A. fulvipectus, A. hermonensis, A. alpicola, A. arianus, A. hyrcanicus, A. ponticus, A. rusiges, A. wardi), Apodemus (A. agrarius, A. chevrieri, A. speciosus, A. peninsulae, A. latronum, A. draco, A. semotus, A. gurkha), and Argenteus (A. argenteus). Serizawa et al. (2000), on the basis of DNA sequences of nuclear (the first exon of the IRBP gene) as well as mitochondrial (cytochrome b) markers, confirmed this classification, but replaced the term 'Sylvaemus group' with 'Sylvaticus group' and introduced a fourth group for the Asiatic species A. gurkha ('Gurkha group').

In the last three decades, the attention of zoologists has mainly been focused on the European species, $A$. sylvaticus Linnaeus 1758, and A. flavicollis Melchior 1834, characterized by widely overlapping ranges and 
by morphological convergence in the southern parts of their ranges. According to several authors (Engländer \& Amtmann, 1963; Witte, 1964; Amtmann, 1965), this convergence is the consequence of introgressive hybridization. However, this possibility was excluded by Niethammer (1969) on morphological evidence, and by numerous authors after allozyme studies (Engel et al., 1973; Debrot \& Mermod, 1977; Benmehdi et al., 1980; Csaikl et al., 1980; Nascetti et al., 1980; Gemmeke \& Niethammer, 1981; Fraguedakis-Tsolis et al., 1983; Nascetti \& Filippucci, 1984; Gebczyński et al., 1986), mtDNA restriction and species-specific PCR amplification patterns (Michaux et al., 1998a,b, 2001; Libois et al., 2001), and sequence studies (Chelomina et al., 1998; Serizawa et al., 2000; Suzuki, Tsuchiya \& Takezaki, 2000).

In Europe, the subgenus Sylvaemus is represented by five species: A. flavicollis, A. sylvaticus, A. alpicola Heinrich 1952, A. microps Kratochvíl \& Rosický, 1952, and A. mystacinus Danford \& Alston 1877 (Fig. 1). Apodemus alpicola, originally described as a high altitude subspecies of $A$. flavicollis, was shown to be a morphologically (Storch \& Lütt, 1989) and genetically (Vogel et al., 1991; Filippucci, 1992) well-defined species. The taxon microps has recently been synonymized with $A$. uralensis (Pallas 1811) (Vorontsov et al., 1992; Filippucci et al., 1996; Mezhzherin, 1996; Bellinvia et al., 1999; Macholán et al., 2001a).

Apodemus mystacinus, occurring on the Balkan Peninsula and the Middle East, is clearly morphologically distinguishable from other Sylvaemus species and therefore was separated into the subgenus Karstomys Martino 1939 by some authors (Rietschel \& Storch, 1974; Storch, 1975). However, the validity of Karstomys has not been generally accepted (Corbet, 1978; Niethammer, 1978; Musser et al., 1996). According to Felten et al. (1973), two subspecies should be recognized for the species: epimelas, distributed on the Balkan Peninsula, and nominal mystacinus of the Middle East (Fig. 1). Storch (1977) hypothesized a specific status for the two taxa, based on differences in the first upper molar found in the Recent as well as in Pleistocene populations. No direct genetic comparison between populations of $A$. mystacinus from different geographical areas has hitherto been carried out.

In North Africa only A. sylvaticus is present, in the Maghreb region. Saint Girons \& Van Bree, 1963), investigating morphological traits, suggested three different subspecies to be present in North Africa: $A$. s. hayi (Waterhouse, 1837), inhabiting the Mediterranean regions of the Maghreb; $A$. s. rufescens Saint Girons \& van Bree, 1963, inhabiting the Hauts Plateau in Algeria and arid forests in Morocco; and A. s. ifranensis, which has a range covering the Middle Atlas from the east of Khénifra to the region of Oulmes and to Ifrane (Saint Girons \& van Bree, 1963; Saint
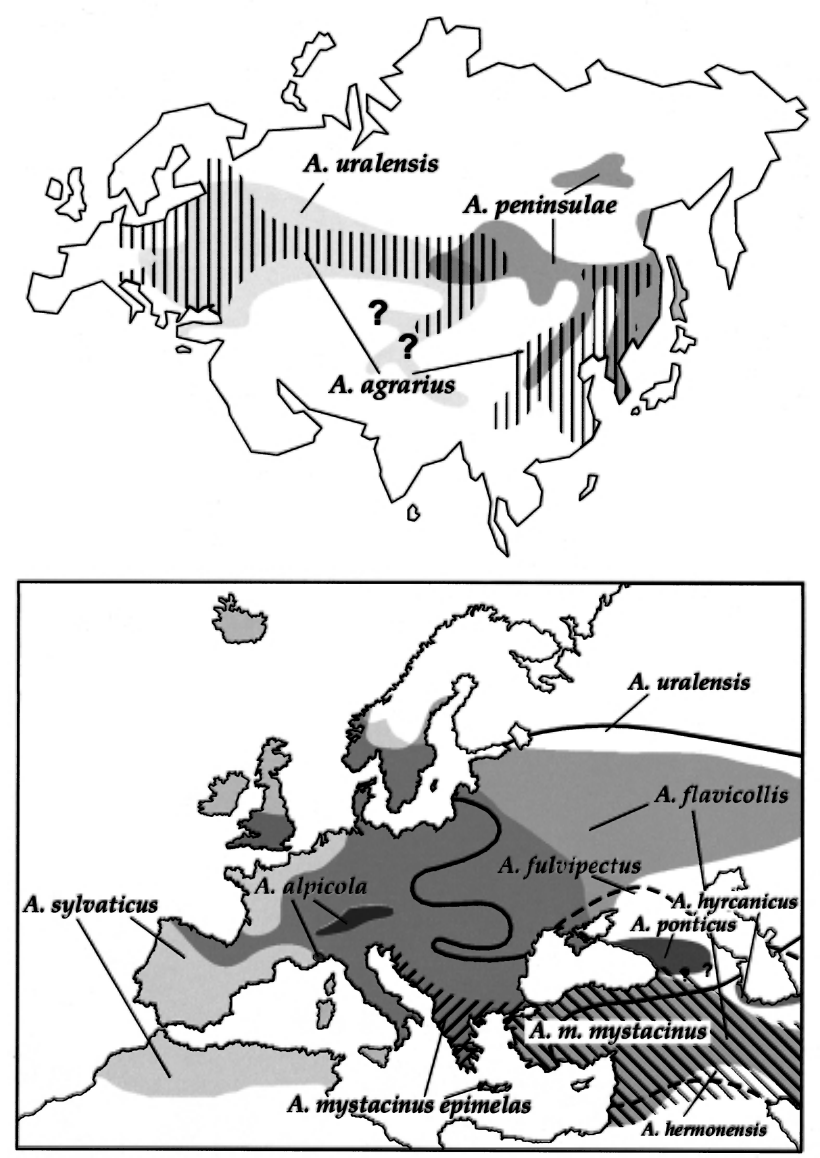

Figure 1. A schematic depiction of the geographical distribution of (top) A. uralensis, A. peninsulae and A. agrarius in Eurasia; and (bottom) A. flavicollis, A. sylvaticus, A. alpicola, $A$. ponticus, A. fulvipectus, $A$. hermonensis, $A$. uralensis, A. hyrcanicus, A. mystacinus epimelas and A. $m$. mystacinus in Europe and the Middle East, A. uralensis is indicated with a solid line A. fulvipectus and A. hermonensis (both indicated with a dashed line) are most probably conspecific. Compiled from Corbet (1978), Musser \& Carleton (1993), Mezhzherin (1997b), Zagorodnyuk et al. (1997), Mitchell-Jones et al. (1999), and Macholán et al. (2001a).

Girons, 1972). However, Kock \& Felten (1979) found no differences between $A$. s. rufescens and $A$. s. hayi and according to Kowalski \& Rzebik-Kowalska (1991) and to Filippucci (1992), there are no differences among the North African populations of A. sylvaticus. Libois et al. (2001), on the basis of mtDNA RFLPs, did not find any genetic difference between the three North African subspecies and suggested combining $A$. s. rufescens and $A$. s. ifranensis within A. s. hayi.

Recently, zoologists have focused on south-eastern Europe and the Middle East, where several taxa, previously assigned to $A$. sylvaticus, have been recognized as distinct species. In Israel, a new species, $A$. hermonensis Filippucci, Simson \& Nevo, 1989, was identified 
by biometric and protein electrophoretic analyses. Filippucci et al. (1989) found A. flavicollis (apart from A. mystacinus) to be the most common species in Israel, instead of A. sylvaticus as then commonly believed.

Several subspecies of A. sylvaticus (uralensis of the southern Ural, charkovensis of Ukraine, mosquensis of the Moscow region, ciscaucasicus of the northern Caucasus, and tscherga of the Altai) appeared to be geographical forms of another species, A. uralensis, according to allozyme data (Mezhzherin \& Mikhailenko, 1991). (Recently, the taxa mosquensis and ciscaucasicus have been asserted to deserve the specific status within the superspecies $A$. uralensis by Orlov et al. (1996), mostly on the basis of cytogenetic studies.) A new species was also described from Ukraine, originally named A. falzfeini (Mezhzherin \& Zagorodnyuk, 1989), and later synonymized with $A$. fulvipectus Ognev, 1924 from the Caucasus (Vorontsov et al., 1992). Vorontsov et al. (1992) used morphological, chromosomal and allozyme data to investigate the systematics of the Sylavemus group in the Caucasus and Transcaucasus. They proposed that four species inhabited those regions (Fig. 1): A. ponticus Sviridenko 1936, previously considered subspecies of A. flavicollis (Mezhzherin, 1991), A. hyrcanicus Vorontsov, Boyeskorov \& Mezhezherin 1992, A. uralensis, and A. fulvipectus Mezhzherin, Boyeskorov \& Vorontsov 1992 (Vorontsov et al., 1992).

In western Anatolia, four Sylvaemus species were suggested by electrophoretic and morphological analyses (Filippucci et al., 1996). Apodemus sylvaticus, previously considered widely distributed in Asian Turkey, was shown to be an extremely rare species there, restricted to a small area near the coast of the Black Sea. On the contrary, A. flavicollis, previously considered to be from the Caucasus and eastern Anatolia only, appeared to be widely distributed throughout the area studied, as also did A. hermonensis, previously known only from Mt. Hermon in Israel. Finally, A. uralensis was found to be confined to the humid mountainous areas of northern Asia Minor. These results were subsequently confirmed by Macholán et al. (2001a) who extended the study to eastern Turkey, Armenia, and to the western, northern and southern parts of Iran.

Nevertheless, our knowledge of the systematics of wood mice from Iran is still incomplete and the data from eastern parts of Iran and Nepal as well are rather fragmentary. Being previously attributed to $A$. sylvaticus according to external morphological characters, populations from this area displayed a higher genetic affinity to A. flavicollis than to A. sylvaticus, although differentiated from both of them (Darviche et al., 1979; Gemmeke \& Niethammer, 1982). Recently, Musser \& Carleton (1993), in their synopsis of mammal species of the world, suggested A. arianus (Blanford 1881) inhabited Iran, and A. wardi (Wroughton 1908) inhabited Nepal, Kashmir, Pakistan, Afghanistan, and north-western Iran. According to these authors, A. fulvipectus (in the north), and A. ponticus (in the north-west) probably also occur in Iran. More recently, Mezhzherin (1997b) and Zagorodnyuk et al. (1997) have suggested A. arianus to be an older synonym of the taxa falzfeini, chorassanicus, fulvipectus, and hermonensis.

Genetic differentiation and/or phylogenetic relationships among species of the genus Apodemus have been studied by many authors using both biochemical and molecular methods (see Michaux et al., 2002 and references therein). Because of the high genetic differentiation between A. agrarius and all other species from the western Palaearctic region, several authors (Bonhomme et al., 1985; Britton-Davidian et al., 1991; Filippucci, 1992; Filippucci et al., 1996; Mezhzherin, 1997b) have proposed Sylvaemus to be a distinct genus. Hartl et al. (1992), studying allozyme differentiation at 36 loci in four Apodemus species (A. sylvaticus, A. flavicollis, A. microps, and A. agrarius), Mus, and Rattus, and using Microtus, Clethrionomys, and Cricetus as outgroups, found A. agrarius to be more distant to other Apodemus species than were Mus and Rattus on a UPGMA phenogram, however, cladistic analysis of the same data showed monophyly of all the Apodemus taxa. Hartl et al. (1992) concluded that the results of electrophoretic studies had been greatly biased because of the unequal rates of genic evolution among the taxa and suggested using a cladistic approach for the inference of phylogenetic relationships within the genus. More recently, monophyly of the genus Apodemus has been corroborated by molecular studies (Chelomina et al., 1998; Serizawa et al., 2000; Michaux et al., 2002). Musser et al. (1996) recommended retention of the generic name Apodemus pending the systematic revision of the entire complex of species.

Notwithstanding conflicting results of different studies regarding phylogenetic relationships both within and among subgenera of the genus Apodemus, recent morphological, biochemical and molecular analyses seem to agree in that there are 3-4 phylogenetic lineages within the genus (Sylvaemus/ Sylvaticus, Apodemus, Argenteus, Gurkha), however, elevating these lineages to separate genera is not substantiated. Although A. mystacinus and all Sylvaemus species most probably form a monophyletic group, relationships within the latter group remain unclear and also evidence supporting inclusion of A. mystacinus within a separate genus Karstomys (Martin et al. 2000) is inconclusive (Michaux et al., 2002).

The purpose of the present study is to extend the analysis carried out by Filippucci (1992) on allozyme 
variation at 28-33 loci in 615 specimens representing 51 populations of seven Apodemus species (A. sylvaticus, A. flavicollis, A. alpicola, A. microps [uralensis], A. hermonensis, A. mystacinus, and A. agrarius), increasing the number of taxa and more than doubling the number of specimens and populations investigated. Data are presented on allozyme variation at 28-38 loci in the following taxa: A. sylvaticus, A. flavicollis, A. alpicola, A. hermonensis, A. uralensis, A. mystacinus epimelas, $A$. $m$. mystacinus, $A$. peninsulae, A. agrarius, and an unknown taxon from northern Iran we provisionally call $A$. cf. hyrcanicus (see Macholán et al., 2001a for details). Genetic differentiation and the phylogenetic relationships within and among species of the genus Apodemus are discussed.

\section{MATERIAL AND METHODS}

Electrophoretic analysis was carried out on 1347 specimens representing 121 populations of ten taxa of Apodemus from Europe, the Middle East and North Africa. Collecting sites, their abbreviations, and numbers of specimens examined for each population are presented in Appendix 1.

Tissues of each specimen were preserved at $-80^{\circ} \mathrm{C}$ until processed. Homogenates for electrophoresis were obtained from portions of muscle or kidney tissue crushed in distilled water. Genic variation was assessed using standard horizontal gel electrophoresis. Homogenates obtained from muscle were processed for the following enzymatic systems: $\alpha$ glycerophosphate dehydrogenase (E.C. 1.1.1.8; $\alpha G p d h$ ), sorbitol dehydrogenase (E.C. 1.1.1.14; Sdh). lactate dehydrogenase (E.C. 1.1.1.27; $L d h-1, L d h-2$ ), malate dehydrogenase (E.C. 1.1.1.37; $M d h-1, M d h-2$ ), malic enzyme (E.C. 1.1.1.40; $\mathrm{Me}-1, \mathrm{Me}-2$ ), isocitrate dehydrogenase (E.C. 1.1.1.42; Idh-1, Idh-2), 6phosphogluconate dehydrogenase (E.C. 1.1.1.44; 6Pgdh), glucose-6-phosphate dehydrogenase (E.C. 1.1.1.49; G6pdh), glyceraldehyde-3-phosphate dehydrogenase (E.C. 1.2.1.12; G3pdh), indophenol oxidase (E.C. 1.15.1.1; Ipo-, Ipo-2), nucleoside phosphorylase (E.C. 2.4.2.1; Np), glutamate-oxalacetate transaminase (E.C. 2.6.2.1; Got-1, Got-2), hexokinase (E.C. 2.7.1.1; Hk-1, Hk-2), creatine kinase (E.C. 2.7.3.2; Ck), adenylate kinase (E.C. 2.7.4.3; $A d k$ ), phosphoglucomutase (E.C. 2.5.7.1; Pgm-1, Pgm-2), esterases (E.C. 3.1.1.1; Est-1, Est-2, Est-3), leucyl aminopeptidase (E.C. 3.4.11; Lap), peptidases (E.C. 3.4.11; Pep-1, Pep2, Pep-3), acid phosphatase (E.C. 3.1.3.2; Acph), adenosine deaminase (E.C. 3.5.4.4; Ada), aldolase (E.C. 4.1.2.13; Aldo), fumarase (E.C. 4.2.1.2; Fum), mannose phosphate isomerase (E.C. 5.3.1.8; $\mathrm{Mpi}$ ), and glucose phosphate isomerase (E.C. 5.3.1.9; Gpi). Homogenates obtained from kidney were processed for alcohol dehydrogenase (E.C. 1.1.1.1; Adh). The electrophoretic pro- cedures used were those described by Filippucci et al., 1988).

Isozymes were numbered in order of decreasing mobility from the most anodal one. Allozymes were numbered according to their mobility, relative to the most common allele (designed 100) in the reference population of $A$. sylvaticus from Burano (SBUR). Allozyme data were analysed using allele frequencies as input. Intrapopulation genetic variation was estimated as the mean number of alleles per locus $(A)$, proportion of polymorphic loci in the population $\left(P_{1 \%}\right)$, mean observed heterozygosity per locus $\left(H_{0}\right)$, and mean expected heterozygosity per locus (genetic diversity, $H_{\mathrm{e}}$; Nei, 1978). Genetic structure within and among conspecific populations was estimated by means of F-statistics (Wright, 1965). The amount of genetic divergence between populations was estimated with the indices of Nei's standard and unbiased genetic distance (Nei, 1972, 1978) and with chord distance introduced by Cavalli-Sforza \& Edwards (1967; see Macholán et al., 2001b for the rationale behind using these indices; see also Swofford et al., 1996 for statistical details). BIOSYS-1 (Swofford \& Selander, 1981) was used for all these procedures. Matrices of Nei's (1978) genetic distances were compared to geographical distances with the NTSYS-pc program (Rohlf, 1997) by comparing the observed with 'random' values of the Mantel $Z$ statistic as obtained from 5000 permutations (Mantel, 1967). Matrices of geographical distances (rounded to $5 \mathrm{~km}$, seas bypassed) were created using Microsoft $^{\odot}$ Encarta $^{\odot}$ World Atlas (1998 edition).

In total, 38 gene loci were studied, however, indices of genetic variation and distance were calculated on a lower number of loci, because for some of the species data were missing at a few loci. The present study includes new as well as previously reported data (Nascetti \& Filippucci, 1984; Filippucci et al., 1989; Filippucci, 1992; Filippucci et al., 1996; Michaux et al., 1996a; Macholán et al., 2001a). Interspecific divergence was calculated on 34 shared loci, whereas intraspecific differentiation was evaluated on 28 loci in A. flavicollis, 29 loci in A. sylvaticus, 32 loci in A. mystacinus, 34 loci in A. alpicola, $A$. agrarius and $A$. peninsulae, and 36 loci in A. hermonensis, A. uralensis and $A$. cf. hyrcanicus.

Two loci (Adh and Acph) studied in Filippucci (1992) and Filippucci et al. (1996) were not included in the evaluation of genetic distances, because for some taxa (A. peninsulae, A. cf. hyrcanicus, and A. m. epimelas) data at these loci were missing. However, four new loci (Est-1, Est-2, Pep-1, and Pep-2) not included in Filippucci (1992) were considered for the analysis of interspecific differentiation.

Dendrograms of genetic relationships among populations within individual species were obtained using 
the neighbour-joining method (Saitou \& Nei, 1987) based both on Nei's (1978) and Cavalli-Sforza \& Edwards' (1967) distances. In order to reveal phylogenetic relationships among the Apodemus species studied, we employed four different methods of phylogenetic inference which are based on different assumptions: maximum-likelihood (Felsenstein, 1981); Fitch-Margoliash procedure; Wagner parsimony based on mutation coding scheme proposed by Murphy (1993) and Murphy \& Doyle (1998); and a method of constructing phylogenetic trees by applying the criterion of parsimony directly to allele frequency data as implemented in the program FREQPARS (Swofford \& Berlocher, 1987). (This program tries to find the tree on which the frequency of each allele undergoes the least possible amount of change, while ensuring that allele frequencies in hypothetical ancestors add to one.)

Nei's (1972) standard distance was used for distance-based phylogenetic methods since (unlike Cavalli-Sforza \& Edwards' procedure) it takes into account new mutations, more likely an explanation than mere drift for allelic differences between wood mouse species. In order to estimate reliability of phylogenetic inference at each node, the bootstrap method of Felsenstein (1985) with 1000 pseudoreplications was used for all phylogenies except those estimated by FREQPARS. The PHYLIP program package (Felsenstein, 1995) was used for all the procedures except when stated otherwise.

\section{RESULTS}

\section{PATTERN OF VARIATION}

Overall, 190 alleles were scored. Thirty-five of them were rare and present with a frequency lower than $1 \%$ in at least one species. The highest number of alleles were found at Ada (12), $\alpha G p d h$ (11), and Me-1 (11). Only a single locus, Lap, out of the 38 analysed loci was monomorphic and fixed for the same allele in all species examined. Three other loci showed alleles with frequencies lower than $1 \%$ in individual species: $M d h$ 2 (with the allele $M d h-2^{92}$ present with $2 \%$ frequency only in the population of A. sylvaticus from the Lepini Mountains), $C k$ (with two rare alleles, 105 and 95, present only in Israeli populations of $A$. m. mystacinus), Adk (with two rare alleles, 90 and 94 , present in populations of A. sylvaticus from the Lepini Mountains and Corsica).

Allele frequencies of the polymorphic and/or discriminant loci in the species analysed are given in Appendix 2. Only alleles with a frequency of at least $1 \%$ within all species were considered for interspecific comparisons. In Table 1, total numbers of alleles observed in each species are given, as well as the number of alleles in common and loci discriminating between pairs of species. Apodemus flavicollis displayed the highest number of alleles in common with other Sylvaemus species, ranging from 34 (with $A$. cf. hyrcanicus) to 46 (with $A$. sylvaticus). In contrast, $A$. agrarius displayed the lowest number of alleles in

Table 1. (A) Total number of loci studied, total number of alleles observed, and number of exclusive alleles with frequency higher or lower than $1 \%$ in each species. (B) Number of alleles in common (above diagonal) and number of discriminant loci (below diagonal) between species

\begin{tabular}{|c|c|c|c|c|c|c|c|c|c|c|}
\hline & SYL & FLA & ALP & HER & URA & HYR & MYS & EPI & PEN & AGR \\
\hline \multicolumn{11}{|l|}{ (A) } \\
\hline No. loci & 38 & 38 & 38 & 38 & 38 & 38 & 38 & 35 & 34 & 37 \\
\hline No. alleles & 81 & 76 & 48 & 62 & 66 & 40 & 71 & 36 & 37 & 45 \\
\hline No. excl.alleles $>1 \%$ & 9 & 2 & - & 4 & 2 & 2 & 12 & 6 & 4 & 15 \\
\hline No. excl.alleles $<1 \%$ & 16 & 7 & - & 4 & 2 & - & 3 & - & - & - \\
\hline \multicolumn{11}{|l|}{ (B) } \\
\hline sylvaticus & - & 46 & 37 & 37 & 40 & 27 & 26 & 18 & 14 & 15 \\
\hline flavicollis & 6 & - & 45 & 43 & 45 & 34 & 33 & 21 & 18 & 15 \\
\hline alpicola & 5 & 1 & - & 37 & 39 & 33 & 27 & 17 & 12 & 11 \\
\hline hermonensis & 6 & 3 & 4 & - & 40 & 30 & 27 & 16 & 14 & 15 \\
\hline uralensis & 7 & 2 & 1 & 4 & - & 34 & 32 & 19 & 14 & 11 \\
\hline cf. hyrcanicus & 7 & 4 & 4 & 6 & 3 & - & 28 & 18 & 15 & 11 \\
\hline mystacinus & 8 & 10 & 11 & 13 & 9 & 10 & - & 27 & 16 & 14 \\
\hline epimelas & 11 & 15 & 18 & 18 & 16 & 17 & 8 & - & 13 & 12 \\
\hline peninsulae & 20 & 20 & 23 & 21 & 21 & 22 & 19 & 21 & - & 19 \\
\hline agrarius & 21 & 22 & 26 & 22 & 26 & 24 & 23 & 22 & 16 & - \\
\hline
\end{tabular}


common with other Apodemus species, ranging from 11 (with A. alpicola, A. uralensis, and A. cf. hyrcanicus) to 19 (with $A$. peninsulae).

\section{A. sylvaticus}

Eighty-one alleles were observed at 38 loci, 25 of them being exclusive to this species (Table 1). Intraspecific analysis was carried out on 29 loci. Twenty loci were polymorphic in the 42 populations analysed, whereas nine loci were monomorphic (Sdh, Idh-2, G6pdh, G3pdh, Ipo-2, Hk-1, Ck, Acph, Lap). Additional loci were included into interspecific comparisons: two of them (Adh, Pgm-1) were polymorphic and seven (Hk2, Est-1, Est-2, Рep-1, Рep-2, Pep-3, Acph) were monomorphic. One exclusive allele was found in North Africa $\left(\alpha G p d h^{104}\right)$, whereas $M e-2^{115}$ was found in Algeria and the Iberian Peninsula. Other alleles exclusive to Spain were found at Mdh-1 (110) and at $M e-2$ (92). Several alleles at numerous loci were exclusive to populations from peninsular Italy: $M d h-2^{92}, M e-2^{94}$, $M e-2^{88}, 6 P g d h^{92}$, Ipo- $1^{82}$, Got- $1^{90}$ (found also in Sardinia), $A d k^{94}, P g m-2^{96}, A d a^{90}, A d a^{85}, A d a^{80}$, and $A l d o^{105}$. Concerning insular populations, Corsica was characterized by four exclusive alleles $L d h-2^{92}, N p^{95}, A d k^{90}$, and Fum $^{96}$. At a fifth locus, an allele Got-2 $2^{92}$ was exclusive to Corsica and Elba. The Sardinian population was characterized by the presence of an exclusive allele Got- $1^{90}$, observed in the mainland population from Penne. Populations from the Balkan Peninsula were characterized by the alleles Got- $1^{110}$ and Ipo- $1^{110}$.

\section{A. flavicollis}

Seventy-six alleles were observed at 38 loci and nine of them were exclusive to this species (Table 1). Intraspecific analysis was carried out on 28 loci. Fourteen loci were polymorphic in 30 populations, whereas 14 loci were monomorphic (Sdh, Ldh-2, Mdh-2, Idh-2, Ipo-1, Ipo-2, Np, G6pdh, Got-2, Ck, Adk, Lap, Aldo, Fum). Another five monomorphic loci (Adh, Hk-2, Est1, Acph, Pep-2) and five polymorphic loci (Me-1, Pgm1, Est-2, Pep-1, Рep-3) were added for interspecific comparisons. Several loci showed alleles exclusive to peninsular Italy: $\alpha G p d h^{104}, L d h-1^{92}, M d h-1^{90}, I d h-1^{90}$, $A d k^{94}, P g m-2^{96}, E s t-3^{107}, A d a^{85}$, and $M p i^{95}$. Two loci, $6 P g d h$ and Est-3, contributed to a partial discrimination of peninsular populations from those sampled in Europe and the Middle East: whereas the allele $6 P g d h^{92}$ reached a mean frequency of 0.68 on the peninsula, it was only 0.19 in other populations. Likewise, the frequency of $E s t-3^{95}$ was as high as 0.99 in peninsular populations, whereas in other parts of Europe the frequency was much lower (0.25) and in the Middle East the allele was absent and replaced by Est- $3^{105}$. Alleles $\alpha G p d h^{106}$ and $H k-1^{104}$ were present only in populations from Israel. At several loci, numerous alleles were found only in European populations:
$A d a^{95}, \quad P g i^{90}$ (the Balkans and Sweden), Pgi ${ }^{104}$ (Germany), $M e-2^{80}$ (Sweden), and $L d h-1^{108}$ (the Alpine populations from Tarvisio and Vorarlberg). Idh-1 ${ }^{100}$, typical of $A$. sylvaticus, was found occasionally in European populations of $A$. flavicollis.

\section{A. hermonensis}

In total, 62 alleles were observed at 38 loci, eight of them being species-specific (Table 1). Intraspecific analysis was carried out on 36 loci in 20 populations; 19 loci were monomorphic (Sdh, Ldh-1, Mdh-1, Mdh2, Idh-2, G6pdh, G3pdh, Ipo-2, Np, Got-2, Hk-1, Hk-2, Adk, Pgm-2, Ap-3, Lap, Aldo, Fum, Mpi). Two additional loci were considered for interspecific comparisons: Acph (monomorphic), and Adh (polymorphic). Three alleles were exclusive to Iranian populations: $L d h-2^{97}, I d h-1^{113}$, and $C k^{95}$. Two alleles were characteristic of Israeli populations: $E s t-3^{95}$ and $A d a^{115}$, and Turkish populations were characterized by $\alpha G p d h^{93}$, 6Pgdh ${ }^{112}$, Ipo-1 $1^{70}$, Pgm-1 $1^{95}$, Ap $-2^{90}$, Est- ${ }^{103}$, and Pgi ${ }^{104}$.

\section{A. alpicola}

Of 48 alleles observed at 38 loci, no allele was exclusive to this species (Table 1). Intraspecific analysis was carried out on 34 loci in two samples. See Filippucci (1992) for allelic frequencies in individual populations. Six loci were polymorphic in the two Italian populations (Appendix 2).

\section{A. uralensis}

Sixty-six alleles were observed at 38 loci, four of them being species-specific (Table 1). Intraspecific analysis was carried out on 36 loci in 15 populations. Seventeen loci were monomorphic $(S d h, L d h-1, L d h-2, M d h$ 1, Mdh-2, Idh-1, Idh-2, Ipo-1, Ipo-2, Got-2, Hk-1, Hk-2, Ck, Adk, Lap, Aldo, Fum). Additional loci were considered for interspecific comparisons: one of them (Acph) was monomorphic and one $(A d h)$ was polymorphic. No allele was exclusive to Europe or Asia Minor.

\section{A. cf. hyrcanicus}

Of 40 alleles observed at 36 loci, two were exclusive to this taxon (Table 1). Intraspecific analysis was carried out on 36 loci in two population samples. Three loci were polymorphic (Me-1, Ada, Est-3).

\section{A. mystacinus}

In total, 71 alleles were observed at 38 loci in populations from the Middle East (A. m. mystacinus), 19 of them being exclusive (Table 1). In the single Balkan specimen from Galičica (A. m. epimelas), 36 alleles at 35 loci were observed, six of them being exclusive. Intraspecific analysis was carried out on 32 loci in seven populations. See Filippucci et al. (1989) for allelic frequencies in individual populations from Israel and Appendix 2 for mean allele frequencies in 
the species. Fifteen loci were found to be monomorphic ( $\alpha$ Gpdh, Sdh, Mdh-1, Mdh-2, Idh-2, G3pdh, Ipo-1, Ipo2, Got-2, Hk-2, Adk, Lap, Aldo, Fum, Pgi). Of the extra loci included in interspecific comparisons, two were monomorphic (Adh, Pep-3) and four were polymorphic (Pgm-1, Acph, Pep-1, Pep-2). Eight loci (Ldh-1, Ldh-2, Me-2, Idh-1, G6pdh, Pep-1, Pep-2, Mpi) were discriminant and four loci (Me-1, 6Pgdh, Est-1, Est-2) were partially discriminant between the Balkan $A$. $m$. epimelas and Anatolian/Israeli populations of $A . m$. mystacinus.

\section{A. agrarius}

Forty-five alleles were observed at 37 loci in this species; 15 of them were species-specific (Table 1). Intraspecific analysis was carried out on 34 loci in two populations. Six loci were polymorphic (see Appendix 2). Filippucci (1992) describes allele frequencies in populations of this species.

\section{A. peninsulae}

Out of 35 alleles observed at 34 loci, four were exclusive (Table 1). The two specimens analysed showed polymorphism only at $M p i$.

\section{GENETIC SUMMARY}

Mean values of genetic variation at the species level are given in Table 2. Values of genetic variation in A. peninsulae are only tentative, because of the small sample size. The overall mean number of alleles per locus ranged from 1.029 in $A$. peninsulae to 1.333 in A. mystacinus. The overall mean proportion of polymorphic loci $\left(P_{1 \%}\right)$ ranged from 0.029 in $A$. peninsulae to 0.306 in $A$. m. mystacinus. Mean observed heterozygosity was about 0.02 in A. sylvaticus and $A$. peninsulae up to about 0.04 in A. flavicollis, A. uralensis, A. hermonensis, A. m. mystacinus, and A. agrarius.
The highest mean values of genetic diversity were observed in $A$. mystacinus $\left(H_{\mathrm{e}}=0.059\right.$, range $0.035-0.080)$ and in A. flavicollis $\left(H_{\mathrm{e}}=0.045\right.$, range 0.000-0.094). Within populations of the latter species, the lowest diversity was found in those from central and southern Italy $\left(H_{\mathrm{e}}=0.038\right.$, range $\left.0.020-0.054\right)$ and from Asia Minor, Iran and Israel $\left(H_{\mathrm{e}}=0.034\right.$, range 0.000-0.087). Alpine, northern-European and Balkan populations displayed higher mean values $\left(H_{\mathrm{e}}=0.067\right.$, range $0.043-0.094$ ).

In $A$. hermonensis, the highest mean values of genetic diversity were observed in populations from southern Iran $\left(H_{\mathrm{e}}=0.069\right.$, range 0.028-0.089), whereas a much lower mean value $\left(H_{\mathrm{e}}=0.03\right.$, range 0.000-0.059) was found in Turkey and Israel. In $A$. uralensis, observed heterozygosity averaged 0.04 in both European and Turkish populations. Except for $A$. peninsulae $\left(H_{\mathrm{e}}=0.011\right)$, which was under-represented in the material under study (see Appendix 1), the lowest mean values of $H_{\mathrm{e}}$ were observed in $A$. sylvaticus $\left(H_{\mathrm{e}}=0.020\right.$, range $\left.0.000-0.069\right)$. In this species, the lowest diversity $\left(H_{\mathrm{e}}=0.016\right.$, range $\left.0.000-0.041\right)$ was found in populations from North Africa, the Iberian Peninsula and central Europe, whereas values nearly twice as high were apparent in Italian (both insular and peninsular populations, $H_{\mathrm{e}}=0.029$, range 0.011-0.052) and Balkan populations $\left(H_{\mathrm{e}}=0.037\right.$, range $0.017-0.069$ ).

Estimates of Wright's F-statistics are given in Table 3. Only samples of $N \geq 7$ individuals were considered for calculations. A slight deficiency of heterozygotes due to inbreeding within conspecific populations was found in A. sylvaticus and A. flavicollis $\left(F_{I S}=0.135\right.$ and 0.155 , respectively) whereas virtually no inbreeding was apparent in A. uralensis $\left(F_{I S}=0.077\right)$ and $A$. hermonensis $\left(F_{I S}=-0.008\right)$. The highest value of $F_{I S}$ was observed in $A$. m. mystacinus $\left(F_{I S}=0.337\right)$. The mean value of $F_{I T}$ ranged from 0.228 in A. uralensis to 0.432 in A. flavicollis and 0.435 in

Table 2. Values of some indices of genetic variation $\left(A\right.$, mean number of alleles per locus; $P_{1 \%}$, proportion of polymorphic loci under $1 \%$ criterion; $H_{0}$, mean observed heterozygosity; $H_{\mathrm{e}}$, mean expected heterozygosity) and mean intraspecific values of Nei (1978) genetic distance within Apodemus species $(D)$

\begin{tabular}{|c|c|c|c|c|c|c|c|c|}
\hline Species & No. loci & No. populations & No. individuals & $H_{\mathrm{o}}$ & $H_{\mathrm{e}}$ & $P_{1 \%}$ & $A$ & $D$ \\
\hline A. sylvaticus & 29 & 42 & 584 & 0.020 & 0.023 & 0.113 & 1.138 & 0.007 \\
\hline A. flavicollis & 28 & 30 & 377 & 0.037 & 0.045 & 0.165 & 1.167 & 0.020 \\
\hline A. alpicola & 33 & 2 & 18 & 0.031 & 0.033 & 0.136 & 1.166 & 0.015 \\
\hline A. hermonensis & 36 & 20 & 98 & 0.037 & 0.040 & 0.107 & 1.100 & 0.019 \\
\hline A. uralensis & 36 & 14 & 105 & 0.042 & 0.045 & 0.146 & 1.160 & 0.007 \\
\hline A. cf. hyrcanicus & 36 & 2 & 8 & 0.028 & 0.027 & 0.069 & 1.070 & 0.000 \\
\hline A. m. mystacinus & 32 & 6 & 146 & 0.038 & 0.059 & 0.306 & 1.333 & 0.011 \\
\hline A. peninsulae & 34 & 1 & 2 & 0.015 & 0.011 & 0.029 & 1.029 & - \\
\hline A. agrarius & 33 & 2 & 9 & 0.040 & 0.035 & 0.121 & 1.121 & 0.027 \\
\hline
\end{tabular}


Table 3. Mean values of coefficients of Wright's Fstatistics and estimates of the number of migrants exchanged between population samples under assumption of island model ( $\mathrm{Nm}$ was approximated by the formula $N m \approx\left(1 / F_{S T}-1\right) / 4 ;$ Wright, 1943). Only samples of $\mathrm{N} \geq 7$ were considered

\begin{tabular}{lrrrr}
\hline Species & \multicolumn{1}{l}{$F_{I S}$} & $F_{I T}$ & $F_{S T}$ & $N m$ \\
\hline A. sylvaticus & 0.135 & 0.392 & 0.297 & 0.652 \\
A. flavicollis & 0.155 & 0.432 & 0.328 & 0.444 \\
A. hermonensis & -0.008 & 0.252 & 0.258 & 0.394 \\
A. uralensis & 0.077 & 0.228 & 0.164 & 0.606 \\
A. m. mystacinus & 0.337 & 0.435 & 0.148 & 1.439 \\
\hline
\end{tabular}

A. m. mystacinus. In the latter species, however, the high value of $F_{I T}$ is largely due to intrapopulation inbreeding since the value of the fixation index is relatively low $\left(F_{S T}=0.148\right.$, the lowest value among the species studied) when compared with A. flavicollis $\left(F_{S T}=0.328\right.$, the highest value). Rather high values of $F_{S T}$ observed in A. flavicollis (0.328), A. sylvaticus (0.297), and A. hermonensis (0.258) indicate that as much as about $26-33 \%$ of genetic variation in these species is due to differentiation among populations, thus indicating extensive interdemic genic differentiation within the species.

\section{INTRASPECIFIC DIFFERENTIATION}

Indices of genetic distance were calculated from allelic frequencies at 28 loci in A. flavicollis, 29 loci in A. sylvaticus, 32 loci in A. mystacinus, 33 loci in A. alpicola and $A$. agrarius, and 36 loci in A. hermonensis, $A$. uralensis and $A$. cf. hyrcanicus. Data for A. alpicola, $A$. agrarius, $A$. hermonensis, $A$. uralensis, and $A$. cf. hyrcanicus are the same as those published previously (Filippucci, 1992; Filippucci et al., 1996; Macholán et al., 2001a). Mean intraspecific values of genetic distance for each species are available upon request from one of the authors (MGF). Although, in general, Cavalli-Sforza \& Edwards' (1967) chord distances performed better than Nei's genetic distances (both standard and unbiased) as revealed by higher cophenetic correlation coefficients (not shown here), Nei's (1978) distance will be presented in the following text since these are by far the most widely quoted, and our results thus can be more easily compared to those published elsewhere.

\section{A. sylvaticus}

The mean value of genetic distance among 42 populations of this species was 0.007 , ranging from 0.000 to 0.049 . The highest genetic distances were found between North African and European populations

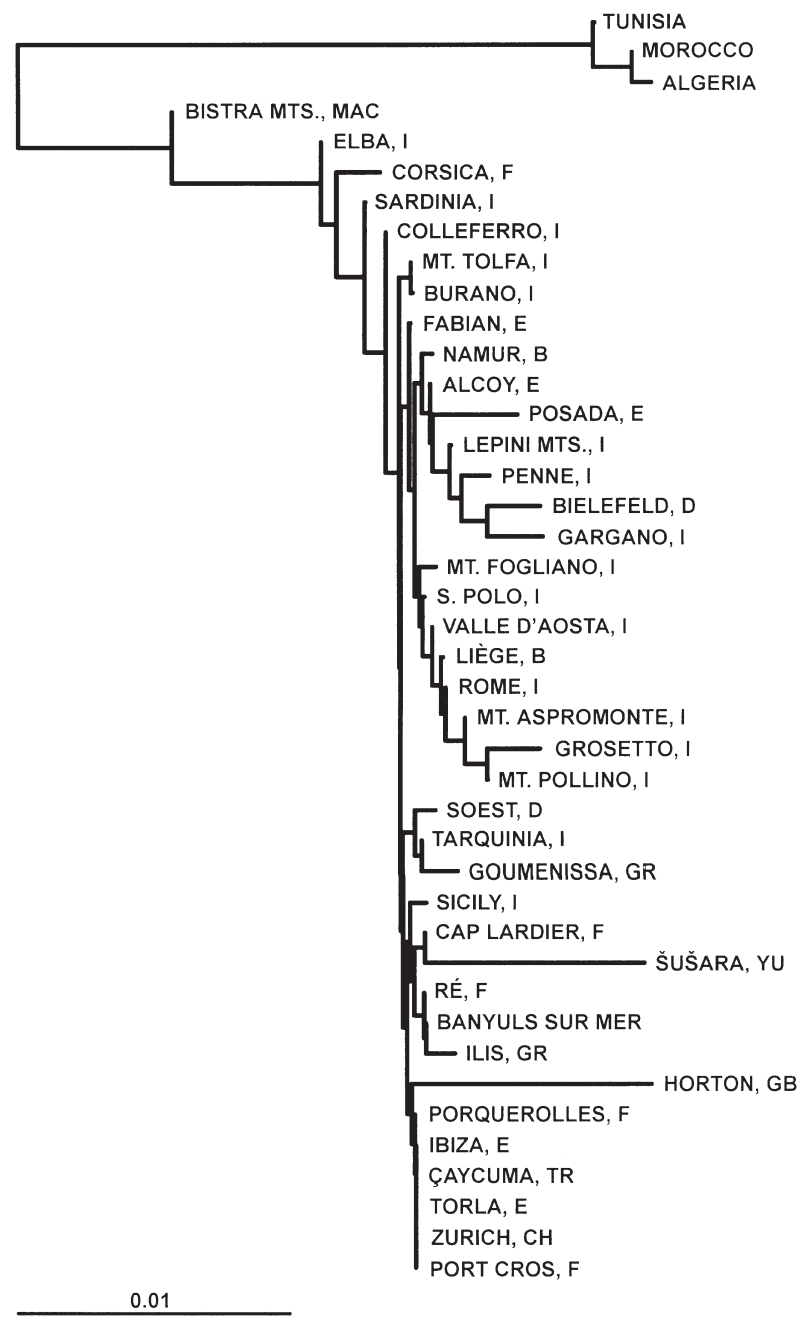

Figure 2. Neighbour-joining tree based on Nei (1978) unbiased distances between $A$. sylvaticus populations using 29 presumptive enzymatic loci. Note: the tree was constructed as unrooted but for convenience, it is shown as mid-rooted here.

( $D=0.036,0.017-0.049)$, while the lowest values were found within the Italian samples (mean $D=0.002$, 0.000-0.007). Genetic distances within North Africa and within Europe, were relatively low (0.000-0.015). Low distance values were also observed between insular Italian (Sicily, Corsica, Sardinia and Elba) and peninsular Italian populations $(D=0.003$, ranging from 0.000 to 0.007$)$. Genetic relationships among the populations sampled are shown in Fig. 2. There are two main groups in the tree, consisting of the African and European populations, respectively. These groups are genetically homogenous with the branching pattern within them being apparently random. The slightly distinct position of the Bistra population may be caused by the small sample size. 


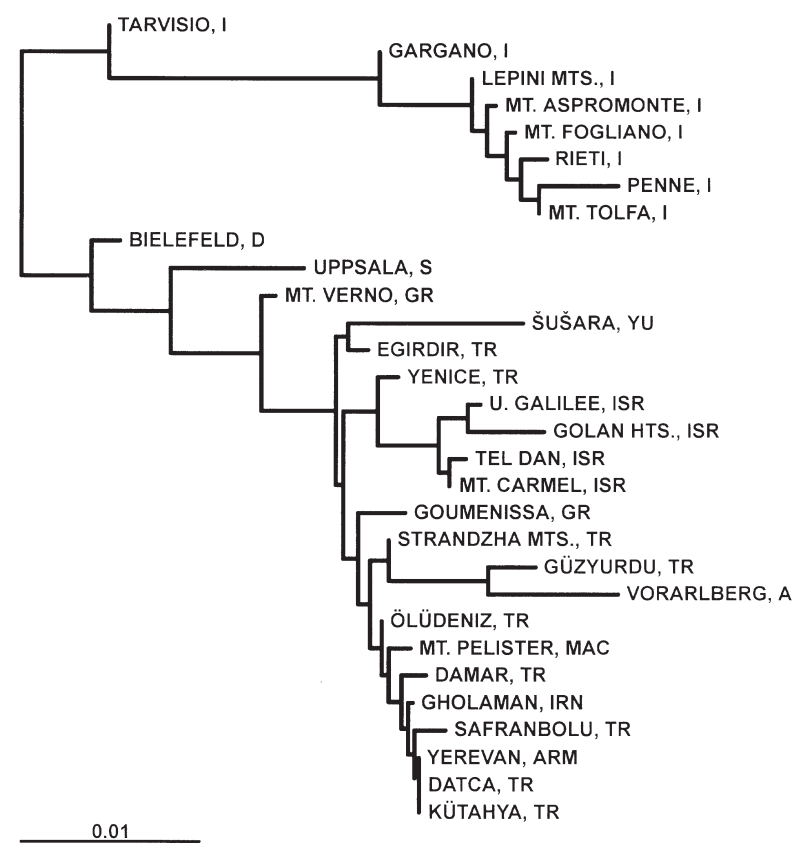

Figure 3. Unrooted neighbour-joining tree depicting interpopulation relationships in A. flavicollis, based on 28 loci. As in all following neigbor-joining trees, a matrix of Nei (1978) distances was used as input. The tree is shown as mid-rooted.

\section{A. flavicollis}

Among 30 populations of this species, the mean value of genetic distance was 0.020 , ranging from 0.000 to 0.070. Low genetic differentiation was observed among populations from northern and central Europe, the Balkan Peninsula, Asia Minor, Iran and Israel (0.000-0.025). The highest value of genetic distance was observed between the Austrian population from Vorarlberg and the Israeli population from Tel Dan $(D=0.025)$. High homogeneity was also observed among Italian peninsular populations $(D=0.002)$. The northern Italian sample from Tarvisio displayed a mean value of genetic distance of 0.009 in comparison with peninsular populations. The highest values of genetic distance in A. flavicollis were found between peninsular populations from Italy and those from other European countries and the Middle East $(D=0.043)$. This is clearly illustrated in Fig. 3 , where all the Italian populations appear to constitute a single clade, with the population from Tarvisio somewhat distinct from others as an apparent genetic transition between the Italian peninsula and the rest of Europe and the Middle East. The latter group (i.e. the Middle East and Europe except Italy) is rather homogenous except the 'northern' populations from Germany and Sweden.

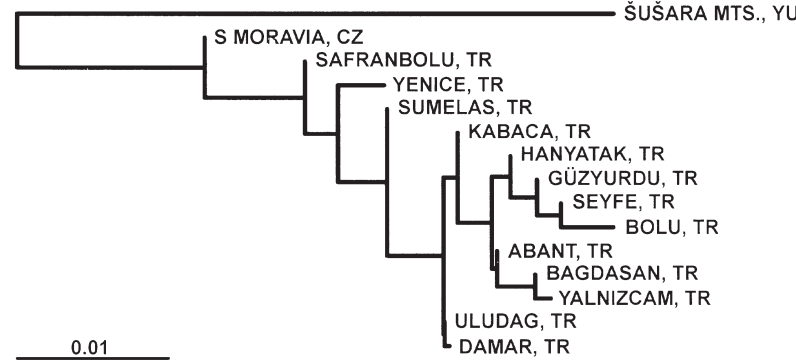

Figure 4. Neighbour-joining tree of $A$. uralensis populations, based on 36 enzymatic loci. The tree was mid-rooted for convenience.

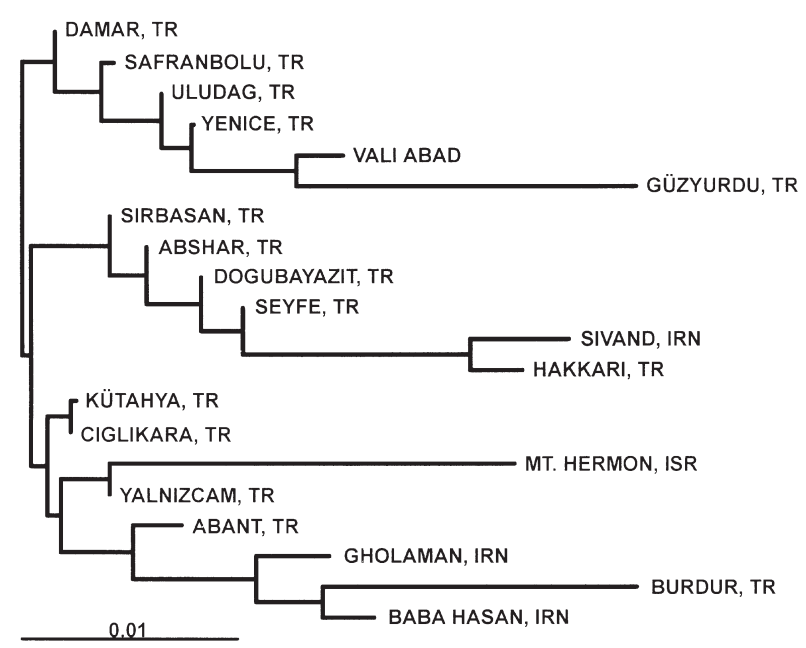

Figure 5. Mid-rooted neighbour-joining tree of A. hermonensis populations, based on 36 loci.

\section{A. uralensis}

The mean value of genetic distance among 14 populations of this species was low $(D=0.019$, ranging from 0.000 to 0.098 ). The Mantel test revealed slight yet significant correlation between genetic distances and geographical distances $\left(r=0.433, \operatorname{Pr}\left[Z_{\text {rand }} \geq Z_{\text {obs }}\right]=0.068\right)$. It is not clear if the distinct position of the Yugoslavian population (Fig. 4) is real or an artefact of small sample size (cf. Appendix 1). More importantly, the population of 'A. microps' from southern Moravia (Czech Republic) appears a sister group of the Turkish clade.

\section{A. hermonensis}

The mean value of genetic distance among 20 populations of this species was 0.019 , ranging from 0.000 to 0.059 . Great heterogeneity in the rate of genetic change was revealed by the neighbour-joining tree (Fig. 5). As in A. uralensis, there is low coincidence between genetic and geographical distances in this 
species (Mantel statistics: $r=0.081, \operatorname{Pr}\left[Z_{\text {rand }} \geq Z_{\text {obs }}\right]=$ $0.165)$.

\section{A. alpicola}

Only two populations of this species were studied (Collardente and Entreves, both in Italy) and the value of genetic distance between them was 0.015 (see Filippucci, 1992).

\section{A. cf. hyrcanicus}

The genetic distance between the two populations from northern Iran (Asalem and Now Kandeh) was 0.000 (Macholán et al., 2001a).

\section{A. mystacinus}

High values of genetic distance were observed between the two subspecies, European A. m. epimelas and A. $m$. mystacinus from Turkey and Israel (mean $D=0.359$ ). Distances between Turkish and Israeli populations were much lower (mean $D=0.028$, ranging from 0.026 to 0.031) (Fig. 6). There was strong correspondence between genetic and geographical distances in $A$. $m$. mystacinus (Mantel statistics: $r=0.981, \operatorname{Pr}\left[Z_{\mathrm{rand}} \geq Z_{\mathrm{obs}}\right]$ $=0.106)$.

\section{A. agrarius}

A relatively low value of genetic distance $(D=0.027)$ was observed among the two populations studied.

\section{INTERSPECIFIC DIFFERENTIATION AND PHYLOGENETIC RELATIONSHIPS}

Several loci, showing fixation for alternative alleles, contributed to the discrimination of the species (Table 1). The lowest number of discriminant loci was found between A. alpicola and A. flavicollis (one, Adh, discriminant, and other three partially discriminant: $M e-1, I d h-1$, and $N p$ ) and A. uralensis (Pep-1 discriminant and $\alpha G p d h, M e-1, N p$, and Est-2 partially dis- criminant). Between A. flavicollis and A. uralensis, two loci were discriminant (Adh, Pep-1) and another three (aGpdh, Idh-1, Est-2) partially discriminant. Apodemus cf. hyrcanicus and A. uralensis were discriminated by three loci $(N p, E s t-2, A d a)$, with $M e-1$ partially discriminant. Between A. flavicollis and $A$. hermonensis, three loci were discriminant (Ipo-2, $N p$, and $P e p-2$ ) and one locus was partially discriminant (Pep-1). A larger number of discriminant loci were found between $A$. sylvaticus and other Sylvaemus species: five in comparison with A. alpicola ( $\alpha G p d h$, Ldh-1, Me-2, Ipo-1, Pep-1); six in comparison with $A$. flavicollis (Adh, $\alpha G p d h, L d h-1, M e-2, I p o-1, N p$ ); seven with A. hermonensis (Adh, $\alpha G p d h, L d h-1, M e-2, I p o-$ 1, Ipo-2, Pep-2), A. uralensis ( $\alpha G p d h, L d h-1, M e-2$, Ipo1, Np, Est-2, Pep-1), and A.cf. hyrcanicus (aGpdh, Ldh-1, Me-2, Ipo-1, Np, Pep-1, Ada).

The discrimination of Karstomys and Sylvaemus species is based on eight loci (between A. m. mystacinus and A. sylvaticus) up to 18 loci (between $A$. $m$. epimelas and both $A$. alpicola and $A$. hermonensis). Finally, the highest numbers of discriminant loci (19-26) were found comparing $A$. agrarius and $A$. peninsulae with Sylvaemus (20-26 loci) and Karstomys (19-24 loci) species.

Values of Nei's genetic distance (Nei, 1972, 1978), based on allele frequencies at 34 loci, are shown in Table 4. The lowest values of interspecific genetic distance were observed between A. alpicola and A. flavi-

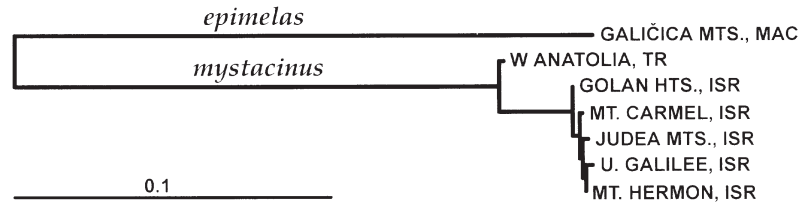

Figure 6. Mid-rooted neighbour-joining tree of populations of $A$. mystacinus, based on 32 enzymatic loci.

Table 4. Values of Nei (1972) standard genetic distance (below diagonal) and Nei (1978) unbiased genetic distance (above diagonal) among species of the genus Apodemus, based on 34 loci

\begin{tabular}{|c|c|c|c|c|c|c|c|c|c|c|}
\hline Taxon & SYL & FLA & ALP & HER & URA & HYR & MYS & EPI & PEN & AGR \\
\hline A. sylvaticus & - & 0.222 & 0.166 & 0.237 & 0.238 & 0.244 & 0.539 & 0.675 & 1.116 & 1.101 \\
\hline A. flavicollis & 0.222 & - & 0.065 & 0.126 & 0.121 & 0.174 & 0.433 & 0.646 & 1.055 & 1.178 \\
\hline A. alpicola & 0.167 & 0.066 & - & 0.139 & 0.120 & 0.132 & 0.398 & 0.670 & 1.071 & 1.209 \\
\hline A. hermonensis & 0.238 & 0.126 & 0.140 & - & 0.232 & 0.253 & 0.509 & 0.687 & 0.965 & 1.032 \\
\hline A. uralensis & 0.238 & 0.122 & 0.121 & 0.232 & - & 0.108 & 0.378 & 0.664 & 0.913 & 1.341 \\
\hline A. cf. hyrcanicus & 0.245 & 0.175 & 0.133 & 0.253 & 0.109 & - & 0.349 & 0.671 & 0.914 & 1.208 \\
\hline A. m. mystacinus & 0.540 & 0.433 & 0.398 & 0.510 & 0.378 & 0.350 & - & 0.417 & 0.877 & 1.312 \\
\hline A. m. epimelas & 0.675 & 0.646 & 0.671 & 0.687 & 0.664 & 0.671 & 0.417 & - & 0.954 & 1.186 \\
\hline A. peninsulae & 1.118 & 1.057 & 1.073 & 0.967 & 0.915 & 0.917 & 0.879 & 0.956 & - & 0.619 \\
\hline A. agrarius & 1.102 & 1.179 & 1.211 & 1.033 & 1.343 & 1.211 & 1.313 & 1.188 & 0.623 & - \\
\hline
\end{tabular}


collis (Nei's unbiased distance $D=0.065$ ) and between A. uralensis and $A$. cf. hyrcanicus $(D=0.108)$. The mean distance value between Karstomys and Sylvaemus was 0.552 , ranging from 0.349 (A. m. mystacinus - A. uralensis) to 0.687 (A. m. epimelas - A. hermonensis). Apodemus peninsulae was genetically closest to $A$. agrarius $(D=0.619)$ while the mean genetic distance between these two species and Sylvaemys-Karstomys was 1.089 , with $A$. peninsulae being closer to Karstomys $(D=0.915)$ than to Sylvaemus $(\mathrm{D}=1.006)$. Apodemus agrarius always displayed distances greater than 1.1 in comparison with all other species.

A

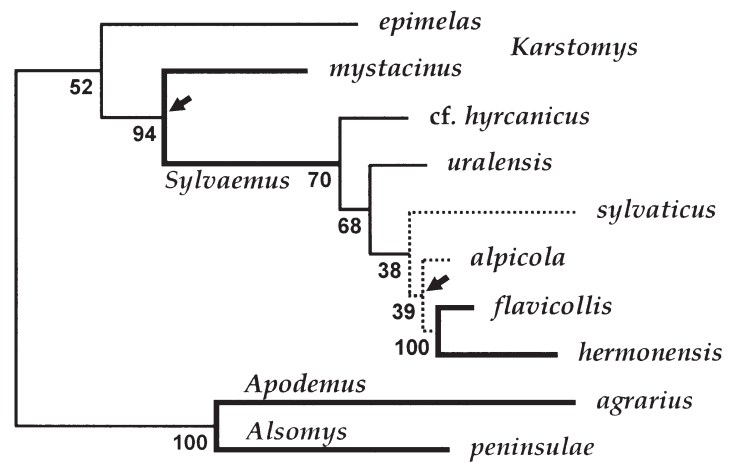

B

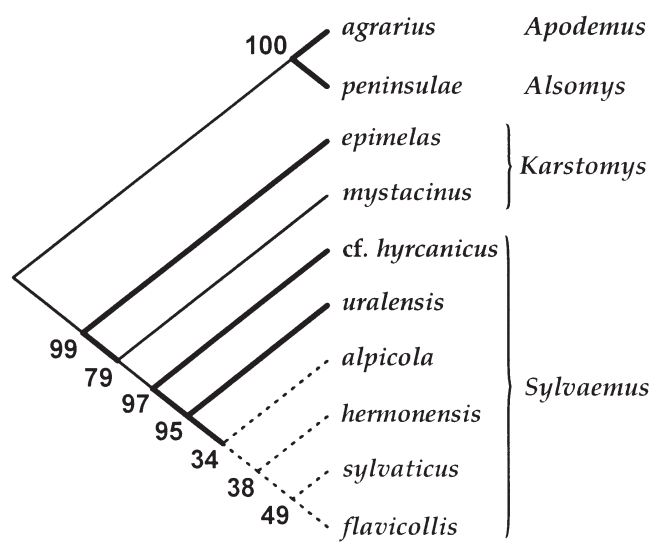

Figure 7. (A) Maximum-likelihood tree showing phylogenetic relationships between the Apodemus species studied. Bootstrap values at each node indicate percentage out of 1000 pseudoreplicated trees. Branches with strong support (bootstrap values $\geq 90$ ) are in bold, branches with very weak support (bootstrap values $\leq 50$ ) are shown as dotted lines. The tree is shown as mid-rooted. Arrows indicate branches that are not significantly different from zero. (B) Wagner parsimony tree based on 'mutation coding scheme' of Murphy (1993) and Murphy \& Doyle (1998). Numbers indicate bootstrap support after 1000 pseudoreplications.
There was general disagreement in the branching pattern of phylogenetic trees revealed by the four different methods employed. This is illustrated by low bootstrap support for most of the nodes (Fig. 7). Nevertheless, there were a few branching patterns common to all or the majority of trees. First, A. agrarius and $A$. peninsulae formed a well-defined clade, distinct from other species. Second, A. m. epimelas and A. m. mystacinus appeared highly differentiated from each other, and indeed these taxa did not even form a monophyletic group in half of the trees. Third, the two Karstomys taxa were sister species to the Sylvaemus group sensu stricto. And finally, A. cf. hyrcanicus and A. uralensis appeared to be sister species to the $A$. sylvaticus-flavicollis-alpicola-hermonensis. It is also of some interest that the rates of allozyme evolution appeared quite uneven among lineages, and A. agrarius, A. sylvaticus and A. hermonensis showed the highest rates in all three phylogenetic methods taking this parameter into account (i.e. maximum-likelihood, Fitch-Margoliash, and FREQPARS parsimony; see the ML tree in Fig. 7). A majority-rule consensus tree constructed from the four trees is shown in Fig. 8. Numbers in parentheses indicate how many times each clade appeared in individual trees. Again, wellsupported clades are formed by $A$. agrarius-A. peninsulae and Sylvaemus with A. mystacinus/epimelas as

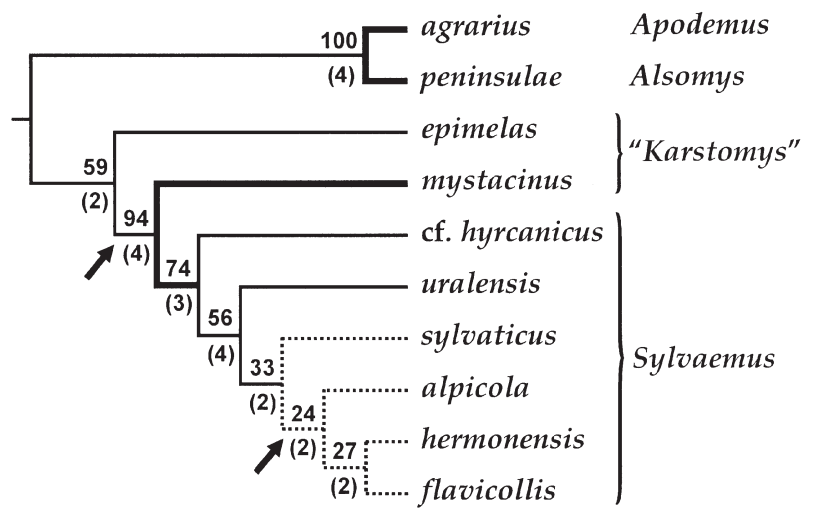

Figure 8. Majority-rule consensus tree based on phylogenies inferred by four different methods (maximumlikelihood; Fitch-Margoliash procedure on Nei (1972) standard distances; character-based Wagner parsimony; and Swofford \& Berlocher's method). Numbers in parenthesses indicate how many times respective nodes appeared in the four trees; bootstrap values are shown above them, indicating percentage out of 3000 trees (three data sets, each consisting of 1000 pseudoreplicated trees, were pooled, excluding Swofford \& Berlocher's parsimony method). Branches with strong support (bootstrap values $\geq 90$ ) are in bold, branches with very weak support (bootstrap values $\leq 50$ ) are shown as dotted lines. Note: since not all methods were used for bootstrapping, the numbers can be biased. 
a sister group to A. cf. hyrcanicus, uralensis, sylvaticus, alpicola, hermonensis, flavicollis.

\section{DISCUSSION}

The values of genetic variation observed in Apodemus are within the range generally reported for this genus (e.g. Gemmeke, 1980; Mezhzherin, 1990; BrittonDavidian et al., 1991), and for other rodents in general (Nevo et al., 1990). According to Selander (1976), marginal populations may display lower values of genetic variation, as a consequence both of founder effect and genetic drift. This may be the case for populations of A. flavicollis from Italy, representing the southern border of the European distribution, and from Iran and Israel, representing the south-eastern border of the species distribution. Moreover, in peninsular Italy the populations of this species are stenotopic, localized and sometimes isolated, mostly inhabiting coniferous and broadleaf deciduous forests.

We attempted to compensate for small sample size by analysing a large number of loci. Values of heterozygosity (and genetic distance) are therefore reliable with a reasonable margin of precision according to Nei (1978), Gorman \& Renzi (1979), and Sage et al. (1986) (but see Archie et al., 1989 for a different opinion).

According to Wright's (1978) suggestions (see also Hartl \& Clark, 1997), moderate to very high genetic differentiation among populations within Apodemus species was indicated by $F_{S T}$ values (range 0.148-0.328). Estimates of the number of migrants exchanged between populations per generation $(\mathrm{Nm})$, can be approximated by the formula $F_{S T} \approx 1 /(4 N m+1)$ (Wright, 1943), and these ranged from an average of 0.394 in A. hermonensis, 0.444 in A. flavicollis, 0.606 in A. uralensis, 0.652 in A. sylvaticus, to 1.439 in $A$. mystacinus. These values suggest lower levels of gene flow in some species, with about one migrant every second generation exchanged in A. sylvaticus and $A$. flavicollis, whereas more than one migrant every generation is exchanged in A. mystacinus (cf. Table 3, right column). It should be noted, however, that the above equation is based on the island model of migration, and it is not clear to what extent the results based on this simple model can be considered reliable.

The mean values of genetic distance among populations are within the range generally observed in other rodent species (Zimmermann et al., 1978; Graf, 1982). Low values observed among European populations of A. sylvaticus ( $D=0.003$; range $0.000-0.015$ ) may be due to the eurytopic niche of this species, favouring gene flow between contiguous populations. Insular populations (Sicily, Corsica, Sardinia and Elba) appeared genetically close to those from the peninsula (Fig. 2). However, mtDNA studies suggested that $A$. sylvaticus is divided into three well-differentiated groups, the first comprising all western European populations from Spain to Scandinavia, the second consisting of those from Italian and Tyrrhenian islands, and the third group consisting of animals from Sicily (Michaux et al., 1998a,b; Libois et al., 2001). This discordance may be a result of different evolutionary rates between mitochondrial and nuclear markers. Under the assumption of neutrality, the expected time for lineage sorting in two idealized and isolated populations is four times longer for nuclear markers than for mitochondrial ones (Avise, 2000). Moreover, in small mammals, it is usually males who are characterized by higher dispersal rates in comparison to more philopatric females. Thus certain mtDNA genes may reflect, with higher fidelity, deeper evolutionary relationships, while biparentally inherited allozymes may reflect recent gene flow among wood mouse populations. Finally, reduced sensitivity of protein electrophoresis at the intraspecific level cannot be ruled out, although in other cases it has proven to be suitable in distinguishing phylogroups within species (e.g. African vs. other populations of A. sylvaticus; Italian vs. other populations of A. flavicollis; $c f$. Figs 1, 2).

The population of $A$. sylvaticus endemic to Elba, being morphologically well-differentiated and characterized by increased body size (Kahmann \& Niethammer, 1971; Filippucci et al., 1984), appeared to be genetically close to mainland populations. The morphological differentiation may be due to selective pressures rather than to founder effect and/or genetic drift (Michaux et al., 1996a). The low genetic distance between Sardinia and Corsica on the one hand, and mainland populations on the other is in agreement with the recent origin of insular populations of $A$. sylvaticus. According to Vigne (1990), this species, as well as other small mammals, appeared in Sardinia and Corsica during the late Neolithic period. Because of the preclusion of land passage between these two islands and the mainland during the Holocene, the presence of these species is probably due to the intensity of shipping since the Neolithic. Analysis of mtDNA restriction patterns (Michaux et al., 1996a) confirmed the anthropogenic origin of wood mice from Sardinia, Corsica and Elba islands. Whereas Sardinia was probably invaded directly from Italy, our results suggest that the Corsican populations originated from Etruria through Elba, as indicated by the presence of allele Got $-2^{92}$ on the latter two islands.

Although genic and morphologic evolution are generally thought to be independent in mammals (Schnell \& Selander, 1981), the comparison of mean values of genetic distance displayed by populations of $A$. sylvaticus with those observed among subspecies in other rodents $(D=0.052$, Zimmermann et al., 1978; $D=$ 0.064, Graf, 1982) should lead to a critical revision 
of the subspecific division of this species. However, as stated above, allozyme analysis may not be sensitive enough to clarify the taxonomy of A. sylvaticus. According to RFLP studies by Michaux et al. (1996a, 1998a), populations from Spain to north-western Europe belong to the same subspecies, A. s. sylvaticus. The origin of these populations on the Iberian Peninsula was also hypothesized by Gemmeke et al. (1987). According to these authors, A. sylvaticus disappeared from south-central Europe during the Upper Pleistocene glacial periods and recolonized this area and northern Europe during the Holocene. Populations on Tyrrhenian islands and peninsular Italy (subspecies A. s. milleri) have a common origin and differ from the north-western subspecies, suggesting that the Alps may act as a biogeographical barrier (Michaux et al., 1996b). Finally, the populations from Sicily are distinctive from the rest of Europe and can be considered a separate subspecies, A. s. dichrurus (Michaux et al., 1998b).

An open question remains about the affinity of Balkan populations. According to Dulić \& Tvrtković (1974) there is considerable confusion concerning the status of A. sylvaticus in this area. High morphological variation was observed in this species and several taxa were described for this region. Therefore, a detailed analysis of Balkan populations is needed.

Between North African populations, low values of genetic distance were observed $(0.000<D<0.001)$, supporting the opinion of Kowalski \& Rzebik-Kowalska (1991) that there are no differences among the populations, which are attributed to the subspecies A. s. hayi. The distance between this taxon and European populations $(D=0.036 ; 0.017-0.049)$ corresponds to distances generally observed among subspecies in other rodents. This genetic homogeneity has also been reflected in a mtDNA restriction pattern study (Libois et al., 2001) and confirms the presence of only a single subspecies in North Africa. According to Gemmeke et al. (1987), the Tunisian wood mice probably originated from south-western Europe, and this hypothesis was supported by Filippucci (1992) and Michaux et al. (1996b, 1998b).

Populations of $A$. flavicollis, which as a species appears more stenotopic than $A$. sylvaticus, are slightly more differentiated. Reduced gene flow between populations (especially within peninsular Italy, where the populations are mostly limited to the Apennine region) results in an increased degree of morphological and biochemical differentiation (Filippucci et al., 1984; Nascetti \& Filippucci, 1984). The highest values of genetic distance were observed between Italian populations from the Apennine Peninsula ascribed to the subspecies $A$. f. geminae, and those from the rest of Europe and the Middle East $(D=0.043,0.006-0.066)$. Two loci (6Pgdh, Est-3) contributed to the differentiation of the peninsular populations, displaying substantial differences in allelic frequencies. The genetic affinity between Middle Eastern and Balkan populations is in agreement with Tchernov's opinion that the genus Apodemus has probably invaded the Middle East from southern Europe relatively recently (Tchernov, 1979).

Relatively high differentiation $(D=0.417)$ was found between $A$. $m$. epimelas from the Balkans and from A. m. mystacinus of the Middle East. Although our analysis is based on a single specimen of epimelas from Galičica, the high value of genetic distance observed and the large number of new alleles at several loci suggest the two taxa could represent two distinct species. This result corroborates the hypothesis of an ancient separation between epimelas and mystacinus, dating to the Pleistocene (Storch, 1977).

In interspecific comparisons, the lowest genetic distances were found between A. flavicollis, A. alpicola, and $A$. hermonensis $(0.060<D<0.139)$, and between $A$. uralensis and $A$. cf. hyrcanicus from northern Iran ( $D=0.108$; the mean value between these two groups was 0.172 ). The allozyme data suggest a recent radiation of species within Sylvaemus (in the narrow sense, i.e. excluding $A$. mystacinus).

As discussed in Macholán et al. (2001a), the taxonomic position of south-eastern taxa is problematic and should be further investigated. A. hermonensis was described from Mt. Hermon in Israel, yet it appears to be a common species in both Asia Minor and Iran (Filippucci et al., 1996; Macholán et al., 2001a). According to the analysis of morphological characters, A. hermonensis is probably a junior synonym of A. fulvipectus (Filippucci et al., 1996). Populations of this species from the Middle East morphologically and ecologically correspond to the taxon chorassanicus, recently included in A. fulvipectus by Musser \& Carleton (1993), and this is further corroborated by comparison of present data with those of Mezhzherin, 1990) and Lavrenchenko \& Likhnova (1995). Diagnostic biochemical characters for A. fulvipectus are the presence of discriminant alleles at $\mathrm{Sdh}$, Sod-2 (Mezhzherin, 1990), $\mathrm{Hb}$ and $\mathrm{Np}$ (Lavrenchenko \& Likhnova, 1995). According to our data, $N p$ and Ipo-2 (=Sod-2) discriminate A. hermonensis from A. flavicollis, A. uralensis, A. cf. hyrcanicus, and A. alpicola.

Populations from Nepal and Iran, previously attributed to A. sylvaticus using morphological characters, displayed a higher affinity with $A$. flavicollis than with A. sylvaticus when studied electrophoretically, although they were differentiated from both of them (Darviche et al., 1979; Gemmeke \& Niethammer, 1982). Recently, Macholán et al. (2001a), documented the presence of three species in Iran (A. hermonensis, A. flavicollis, A. cf. hyrcanicus), of which A. hermo- 
nensis was the most widespread. Mezhzherin (1997b) and Zagorodnyuk et al. (1997) synonymized the taxa falzfeini, chorassanicus, fulvipectus, and hermonensis with Iranian arianus, the latter taxon being the oldest known synonym. Recently, Kryštufek \& Vohralík (2001) and Kryštufek (2002), on morphological criteria, have asserted Apodemus iconicus Heptner, 1948 to be a valid older synonym of $A$. hermonensis. Nonetheless, the relationship of the Middle Eastern A. flavicollis to the Caucasian A. ponticus, the affinity of Apodemus sp. (provisionally named $A$. cf. hyrcanicus in Macholán et al. (2001a) and in this paper) to $A$. hyrcanicus described from Talysh (Mezhzherin et al., 1992; Vorontsov et al., 1992), and the systematic status of $A$. arianus and $A$. wardi remain unclear.

The mean value of genetic distance between $A$. sylvaticus and other Sylvaemus species was 0.22 , indicating that the separation from a common ancestor occurred approximately one million years ago (according to Nei's (1975) formula, T $=5 \times 10^{6} \mathrm{D}$ ). This estimate is in agreement with fossil records (Michaux \& Pasquier, 1974), as well as with the results of rDNA analysis by Suzuki et al. (1990), although it is about four times higher than the allozyme-based estimate of Gebczyński et al. (1986). Conversely, this is two to four times lower than estimates of Serizawa et al. (2000) based on nucleotide sequence data.

Within Sylvaemus (excluding mystacinus and epimelas), the phylogenetic relationships are unresolvable by protein electrophoresis, partly owing to rapid adaptive radiation of the group and partly because of limitations of the method. The branching patterns presented in this paper differ from those published previously (e.g. Mezhzherin, 1990; Filippucci, 1992; Filippucci et al., 1996; cf. Fig. 8) mainly in the placement of $A$. sylvaticus, which has usually been outside other species. However, previous allozyme studies almost exclusively used the UPGMA for depicting genetic relationships among species of Apodemus, yet it has been shown that the method is inappropriate when there are deviations from ultrametricity (i.e. when the assumption of a molecular clock is violated; see Swofford et al., 1996 for details). It is also known that taxa with presumed higher rates of genic change tend to appear most distant in UPGMA phenograms, as do, for example, A. sylvaticus, A. hermonensis and A. agrarius in this paper (UPGMA trees not shown here).

The genetic differentiation between A. mystacinus/epimelas and Sylvaemus corresponds to that generally observed between morphologically well-differentiated species of small mammals. Although the former pair of species have appeared genetically diversified from the latter group (e.g. Britton-Davidian et al., 1991; Filippucci, 1992;
Mezhzherin, 1997a; this paper), the validity of Karstomys remains unclear.

Apodemus peninsulae appeared closer to A. agrarius than to A. mystacinus / epimelas and other Sylvaemus species. This corresponds to Mezhzherin \& Zykov (1991), Bellinvia et al. (1999), and Serizawa et al. (2000) (but see Suzuki et al., 1990). Musser et al.'s (1996) decision of including A. agrarius and A. peninsulae in the same Apodemus-group thus seems appropriate. High genetic distances between $A$. agrarius/A. peninsulae and other species $(D=1.10-1.32)$ are similar to those generally observed among different genera of rodents. For instance, Graf (1982) found an average value of $D=0.75$ within Arvicolidae, Honeycutt \& Williams (1982) found $D=1.01$ in Geomyinae, and Filippucci \& Kotsakis (1995) reported $D=1.69$ in Myoxidae. High values of genetic distance between $A$. agrarius and other European species of Apodemus have been reported in the majority of papers investigating allozyme variation in these species. Moreover, the subgenus Apodemus did not appear to be more closely related to Sylvaemus than to Mus and/or Rattus (Bonhomme et al., 1985; Mezhzherin, 1997a). However, here we are faced with the same problem as discussed in the case of $A$. sylvaticus (see above) of allozyme evolution within lineages, as was suggested by Hartl et al. (1992). According to these authors paraphyly of the genus Apodemus, although supported by the UPGMA clustering method based on the results of allozyme studies, is not substantiated when the parsimony method is applied to the data. Unfortunately as no outgroup was used in this study we cannot resolve this problem even though appropriate methods of phylogenetic inference, including two parsimony approaches, were used. Including more Apodemus taxa from south-eastern Asia and the Far East as well would be desirable.

\section{CONCLUSIONS}

From the results obtained from the electrophoretic analysis of 1347 specimens of ten wood mice taxa from Europe, the Middle East and North Africa, we conclude that:

1 Of 38 loci scored, a single locus, Lap, was found to be monomorphic and fixed for the same allele, while rare (private) alleles appeared at three other loci, $M d h-2, C k$ and $A d k$, at frequencies less than $1 \%$. The taxa investigated had from 11 (between $A$. agrarius and A. uralensis, A. cf. hyrcanicus, A. alpicola) to 46 (between A. sylvaticus and A. flavicollis) common alleles.

2 The mean number of alleles $(A)$ per locus ranged from 1.029 to 1.333 ; high variation was found in the mean proportion of polymorphic loci $\left(P_{1 \%}=\right.$ 
0.029-0.306). Mean observed heterozygosity $\left(H_{0}\right)$ ranged from about $2 \%$ (A. sylvaticus, $A$. peninsulae) to about $4 \%$ (A. flavicollis, A. uralensis, A. hermonensis, A. m. mystacinus, A. agrarius). The highest values of genetic diversity were found in A. mystacinus $\left(H_{\mathrm{e}}=0.059\right)$ and A. flavicollis $\left(H_{\mathrm{e}}=0.045\right)$.

3 Estimates of Wright's F-statistics, measured in samples of $N \geq 7$ only, ranged from $F_{\text {IS }}=-0.008$ (A. hermonensis) to $F_{\mathrm{IS}}=0.155$ (A. flavicollis), $F_{\mathrm{IT}}=0.228$ (A. uralensis) to $F_{\mathrm{IT}}=0.435$ (A. m. mystacinus), and $F_{\mathrm{ST}}=0.148$ (A. m. mystacinus) to $F_{\mathrm{ST}}=0.328(A$. flavicollis).

4 Genetic distances were generally low between populations within individual species, the only exception being the distance between the two subspecies of $A$. mystacinus, European epimelas and mystacinus from the Middle East (Nei's $D=0.359$ ), leading us to suggest the specific status for these taxa. Regardless of a rather random genetic pattern within species, several apparent discontinuities were revealed by neighbour-joining analyses in some species. First, populations of A. sylvaticus from North Africa constitute a separate lineage, clearly distinct from Europe. Second, Italian populations of A. flavicollis are distinguished from those of the rest of Europe and the Middle East, with the population from Tarvisio being intermediate between the two clades. Conversely, even though the southern Moravian population of ' $A$. microps' appeared somewhat differentiated from those of $A$. uralensis from Asia Minor, their inclusion within the same species seems well substantiated.

5 Apodemus agrarius and A. peninsulae are sister taxa and should be included in the same group of species, as already suggested by Musser et al. (1996). 6 Apodemus mystacinus and A. epimelas appear sister taxa to other species of the Sylvaemus group, in agreement with conslusions of Musser et al. (1996) and Serizawa et al. (2000), although validity of the subgeneric name Karstomys for the former two taxa remains unclear.

7 Within the Sylvaemus group in the narrow sense (i.e. excluding $A$. mystacinus and $A$. epimelas), the phylogenetic relationships between species are unclear as the four different phylogenetic methods yielded incongruent results. However, A. cf. hyrcanicus and $A$. uralensis appeared outside the group $A$. sylvaticus-A. flavicollis-A. alpicola-A. hermonensis in the majority of trees.

To resolve the last point, more data (and possibly nucleotide sequences) are needed. However, even additional molecular data and genealogies may not resolve the Sylvaemus phylogeny since a mosaic neutral character evolution may result from rapid speciation events and radiation of the wood mice species. Further investigation is necessary for $A$. hyrcanicus, $A$. ful- vipectus, A. arianus, A. wardi and $A$. ponticus from type localities, as well as other species from central Asia (such as $A$. rusiges, endemic to north India: Musser \& Carleton, 1993), and from south-eastern European taxa vohlynensis, mosquensis, and ciscaucasicus (Orlov et al., 1996). A comparison between European and Asiatic species (especially with $A$. argenteus, presently included in a separate group of species) with an appropriate outgroup will be necessary for correct inference of the evolutionary relationships within the genus and to test the alternative hypotheses of whether Apodemus is monophyletic or polyphyletic.

\section{ACKNOWLEDGEMENTS}

The authors are grateful to P. Benda, S. Ciarlantini, M. Coppola, M. Cristaldi, V. Fadda, D. Frynta, I. Horáček, B. Kryštufek, H. Meinig, G. Reggiani, J. Sádlová, S. Simson, A. Tondina, V. Vohralík, and J. Zima for kindly providing material and/or help in the field. Heidi C. Hauffe and an anonymous referee are acknowledged for language revision and useful comments on earlier versions of the paper.

\section{REFERENCES}

Amtmann E. 1965. Biometrische Untersuchungen zur introgressiven Hybridisation der Waldmaus (Apodemus sylvaticus Linné, 1758) und der Gelbhalsmaus (Apodemus tauricus Pallas, 1811). Zeitschrift für Zoologische Systematik und Evolutionsforschung 3: 103-156.

Archie JW, Simon C, Martin A. 1989. Small sample size does decrease the stability of dendrograms calculated from allozyme-frequency data. Evolution 43: 678-683.

Avise JC. 2000. Phylogeography. The history and formation of species. Cambridge, Massachusetts: Harvard University Press.

Bellinvia E, Munclinger P, Flegr J. 1999. Application of the RAPD technique for a study of the phylogenetic relationships among eight species of the Genus Apodemus. Folia Zoologica 48: 241-248.

Benmehdi F, Britton-Davidian J, Thaler L. 1980. Premier apport de la génétique biochimique des population à la systematique des mulots de France continentale et de Corse. Biochemical Systematics and Ecology 8: 309-315.

Bonhomme F, Iskandar D, Thaler L, Petter F. 1985. Electromorphs and phylogeny in muroid rodents. In: Luckett WP, Hartenberger JL, eds. Evolutionary relationships among rodents. London: Plenum Press, 671-683.

Britton-Davidian J, Vahdati M, Benmehdi F, Gros P, Nancé V, Croset H, Guerassimov S, Triantaphyllidis C. 1991. Genetic differentiation in four species of Apodemus from Southern Europe: A. sylvaticus, A. flavicollis, A. agrarius and A. mystacinus (Muridae, Rodentia). Zeitschrift für Säugetierkunde 56: 25-33. 
Cavalli-Sforza LL, Edwards AWF. 1967. Phylogenetic analysis: models and estimation procedures. Evolution 32: 550-570.

Chelomina GN, Suzuki H, Tsuchiya K, Moriwaki K, Lyapunova EA, Vorontsov NN. 1998. Sequencing of the mtDNA cytochrome $b$ gene and reconstruction of the maternal relationships of wood and field mice of the genus Apodemus (Muridae, Rodentia). Russian Journal of Genetics 34: $529-539$

Corbet GB. 1978. The mammals of the Palaearctic region: a taxonomic review. London: British Museum (Natural History).

Csaikl F, Engel W, Schmidtke J. 1980. On the biochemical systematics of three Apodemus species. Comparative Biochemistry and Physiology 65: 411-414.

Darviche D, Benmehdi F, Britton-Davidian J, Thaler L. 1979. Données préliminaires sur la systématique biochimique des genres Mus et Apodemus en Iran. Mammalia 43: $427-430$

Debrot S, Mermod C. 1977. Chemiotaxonomie du genre Apodemus Kaup, 1827 (Rodentia, Muridae). Revue Suisse de Zoologie 84: 521-526.

Dulić B, Tvrtković. 1974. Some problems of taxonomy of Apodemus sylvaticus Linné, 1758 and Apodemus flavicollis Melchior, 1834 in Yugoslavia. In: Kratochvíl J, Obrtel R, eds. Symposium Theriologicum II. Proceedings of the International Symposium on Species and Zoogeography of European Mammals, Brno 1971. Praha: Academia, 183-189.

Engel W, Vogel W, Voiculescu I, Ropers HH, Zenzes MT, Bender K. 1973. Cytogenetic and biochemical differences between Apodemus sylvaticus and Apodemus flavicollis, possibly responsible for the failure to inbreed. Comparative Biochemistry and Physiology 44b: 1165-1173.

Engländer H, Amtmann E. 1963. Introgressive Hybridisation von Apodemus sylvaticus und Apodemus tauricus. Westeuropa. Die Naturwissenschaften 7: 312-313.

Felsenstein J. 1981. Evolutionary trees from gene frequencies and quantitative characters: finding maximum likelihood estimates. Evolution 35: 1229-1242.

Felsenstein J. 1985. Confidence limits on phylogenies: an approach using the bootstrap. Evolution 39: 783-791.

Felsenstein J. 1995. PHYLIP (Phylogeny Inference Package), Version $357 c$. University of Washington.

Felten H, Spitzenberger F, Storch G. 1973. Zur Kleinsäugerfauna West-Anatoliens. Teil II. Senckenbergiana Biologica 54: 227-290.

Filippucci MG. 1992. Allozyme variation and divergence among European, Middle Eastern, and North African species of the genus Apodemus (Rodentia, Muridae). Israel Journal of Zoology 38: 193-218.

Filippucci MG, Cristaldi M, Tizi L, Contoli L. 1984. Dati morfologici e morfometrici in popolazioni di. Apodemus ( $S y l$ vaemus) dell'Italia centro-meridionale determinati elettroforeticamente. In: Contoli L, Cristaldi M, Filippucci MG, Tizi L, Vigna-Taglianti A, eds. Recenti acquisizioni sul genere. Apodemus in Italia. Bologna: Supplemento alle Ricerche di Biologia della Selvaggina IX, 85-126.

Filippucei MG, Kotsakis T. 1995. Biochemical systematics and evolution of Myoxidae. In: Filippucci MG, ed. Proceedings of 2nd Conference on Dormice (Rodentia, Myoxidae). Hystrix (n.s) 6, 77-97.

Filipucci MG, Rodinò E, Nevo E, Capanna E. 1988. Evolutionary genetics and systematics of the garden dormouse, Eliomys Wagner, 1840. 2-Allozyme diversity and differentiation of chromosomal races. Bollettino di Zoologia 55: 47-54.

Filippucci MG, Simson S, Nevo E. 1989. Evolutionary biology of the genus Apodemus Kaup, 1829 in Israel. Allozymic and biometric analyses with description of a new species: Apodemus hermonensis (Rodentia, Muridae). Bollettino Di Zoologia 56: 361-376.

Filippucci MG, Storch G, Macholán M. 1996. Taxonomy of the genus Sylvaemus in western Anatolia - morphological and electrophoretic evidence (Mammalia: Rodentia: Muridae). Senckenbergiana Biologica 75: 1-14.

Fraguedakis-Tsolis SE, Chondropoulos BP, Lykakis JJ, Ondrias JC. 1983. Taxonomic problems of woodmice, Apodemus ssp., of Greece approached by electrophoretic and immunological methods. Mammalia 47: 333-337.

Gebczyński M, Nielsen JT, Simonsen V. 1986. An electrophoretic comparison between three sympatric species of rodents from Jutland, Denmark. Hereditas 104: $55-59$.

Gemmeke H. 1980. Proteinvariation und Taxonomie in der Gattung Apodemus (Mammalia, Rodentia). Zeitschrift für Säugetierkunde 45: 348-365.

Gemmeke H, Niethammer J. 1981. Die Waldmäuse Apodemus sylvaticus und A. flavicollis vom Monte Gargano (Süditalien). Zeitschrift für Säugetierkunde 46: 162-168.

Gemmeke H, Niethammer J. 1982. Zur Charakterisierung der Waldmäuse (Apodemus) Nepals. Zeitschrift für Säugetierkunde 47: 33-38.

Gemmeke H, Radtke M, Niethammer J. 1987. Zur innerartlichen Proteinvariation bei der Waldmaus (Apodemus sylvaticus). Zeitschrift für Säugetierkunde 52: 242-247.

Gorman GC, Renzi J Jr. 1979. Genetic distance and heterozygosity estimates in electrophoretic studies: effects of sample size. Copeia 1979: 242-249.

Graf JD. 1982. Génétique biochimique, zoogéographie et taxonomie des Arvicolidae (Mammalia, Rodentia). Revue Suisse de Zoologie 89: 749-787.

Hartl DL, Clark AG. 1997. Principles of population genetics, 3rd edn. Sunderland, Massachusetts: Sinauer Associates, Inc.

Hartl GB, Suchentrunk F, Nadlinger K, Willing R, Markowski J, Ansorge H. 1992. Inconsistency of biochemical evolutionary rates affecting allozyme divergence within the genus Apodemus (Muridae: Mammalia). Biochemical Systematics and Ecology 20: 363-372.

Honeycutt RL, Williams SL. 1982. Genetic differentiation in pocket gophers of the genus Pappageomys, with comments on intergeneric relationships in the subfamily Geomyinae. Journal of Mammalogy 63: 208-217.

Kahmann H, Niethammer J. 1971. Die Waldmaus (Apodemus) von der Insel Elba. Senkenbergiana Biologica 52: 381-392.

Kock D, Felten H. 1979. Typen und Typus-Lokalität von Apodemus sylvaticus rufescens Saint Girons and Van Bree, 
1963 (Mammalia, Rodentia, Muridae). Senckenbergiana Biologica 60: 277-283.

Kowalski K, Rzebik-Kowalska B. 1991. Mammals of Algeria. Wroclaw: Ossolineum Publishing House, Polish Academy of Sciences.

Kryštufek B. 2002. Identity of four Apodemus (Sylvaemus) types from the eastern Mediterranean and the Middle East. Mammalia 66: in press.

Kryštufek B. Vohralík V. 2001. Mammals of Turkey and Cyprus. Koper: Zgodovinsko društvo za južno Primorsko.

Lavrenchenko LA, Likhnova OP. 1995. Allozymic and morphological variability in 3 syntopic species of wood mice from the subgenus Sylvaemus (Rodentia, Muridae, Apodemus) from Daghestan. Zoologicheskii Zhurnnal 74: 107-119 (in Russian with English abstract).

Libois RM, Michaux JR, Ramalhino MG, Maurois C, Sarà M. 2001. On the origin and systematics of the northern African wood mouse (Apodemus sylvaticus) populations: a comparative study of mtDNA restriction patterns. Canadian Journal of Zoology 79: 1503-1511.

Macholán M, Filippucci MG, Benda P, Frynta D, Sádlová J. 2001a. Allozyme variation and systematics of the genus Apodemus (Muridae, Rodentia) in Asia Minor and Iran. Journal of Mammalogy 82: 799-813.

Macholán M, Filippucci MG, Zima J. 2001b. Genetic variation and zoogeography of pine voles of the Microtus subterraneus/majori group in Europe and Asia Minor. Journal of Zoology 255: 31-42.

Mantel NA. 1967. The detection of disease clustering and a generalized regression approach. Cancer Research 27: 209-220.

Martin Y, Gerlach G, Schlotterer C, Meyer A. 2000. Molecular phylogeny of European muroid rodents based on complete cytochrome $b$ sequences. Molecular Phylogenetics and Evolution 16: 37-47.

Mezhzherin SV. 1990. Allozyme variation and genetic divergence of wood mice of the subgenus Sylvaemus (Ognev et Vorobiev). Genetika 26: 1046-1054 (in Russian).

Mezhzherin SV. 1991. On specific distinctness of Apodemus (Sylvaemus) ponticus (Rodentia, Muridae). Vestnik Zoologii 1991(6): 34-40 (in Russian, with English summary).

Mezhzherin SV. 1996. Genetic relatedness and species identity of the wood mice (Rodentia, Muridae, Sylvaemus) from Pamiro-Alai. Izvestiya RAN, Seriya Biologicheskaya 1996 (1): 30-38 (in Russian, with English summary).

Mezhzherin SV. 1997a. Genetic differentiation and phylogenetic relationships among Palearctic mice (Rodentia, Muridae). Genetika 33: 78-86 (in Russian, with English summary).

Mezhzherin SV. 1997b. Revision of mice genus Apodemus (Rodentia, Muridae) of Northern Eurasia. Vestnik Zoologii 31: 29-41 (in Russian, with English abstract).

Mezhzherin SV, Boyeskorov GG, Vorontsov NN. 1992. Genetic relations between European and Transcaucasian mice of the genus Apodemus Kaup. Genetika 28: 111-121 (in Russian, with English summary).

Mezhzherin SV, Mikhailenko AG. 1991. On the species identity of Apodemus sylvaticus tscherga (Rodentia,
Muridae) of the Altai Mts. Vestnik Zoologii 1991(3): 35-44 (in Russian).

Mezhzherin SV, Zagorodnyuk IV. 1989. A new species of mice of the genus Apodemus (Rodentia, Muridae). Vestnik Zoologii 1989 (4): 55-59 (in Russian).

Mezhzherin SV, Zykov AE. 1991. Genetic divergence and allozyme variability in mice genus Apodemus s. lato (Muridae, Rodentia). Tsitologiya I Genetika 25: 51-58 (in Russian).

Michaux JR, Chevret P, Filippucci MG, Macholán M. 2002. Phylogeny of the genus Apodemus with a special emphasis to the subgenus Sylvaemus using the nuclear IRBP gene and two mitochondrial markers: cytohrome $\mathrm{b}$ and 12S rRNA. Molecular Phylogenetics and Evolution, in press.

Michaux JR, Filippucci MG, Libois RM, Fons R, Matagne RF. 1996a. Biogeography and taxonomy of Apodemus sylvaticus (the woodmouse) in the Thyrrhenian region: enzymatic variations and mitochondrial DNA restriction pattern analysis. Heredity 76: 267-277.

Michaux JR, Libois R, Fons R. 1996b. Différentiation génétique et morphologique du mulot, Apodemus sylvaticus, dans le bassin méditerranéen occidental. Vie et Milieu 46: 193-203.

Michaux JR, Kinet S, Filippucci MG, Libois R, Besnard A, Catzeflis F. 2001. Molecular identification of three sympatric species of wood mice (Apodemus sylvaticus, A. flavicollis, A Alpicola) in western Europe (Muridae: Rodentia). Molecular Ecology Notes 1: 260-263.

Michaux JR, Libois RM, Ramalhinho MG, Maurois C. 1998a. On the mitochondrial restriction patterns variability of the Iberian wood mouse (Apodemus sylvaticus). Comparison with other west Mediterranean populations. Hereditas 129: $187-194$.

Michaux JR, Sarà M, Libois RM, Matagne RF. 1998b. Is the woodmouse (Apodemus sylvaticus) of Sicily a 'separate' species? Belgian Journal of Zoology 128: 209-212.

Michaux J, Pasquier L. 1974. Dynamique des populations de Mulots (Rodentia, Apodemus) en Europe durant le Quaternaire. Premières données. Bulletin de la Societé Géologique Française 7: XVI: 431-439.

Mitchell-Jones AJ, Amori G, Bogdanowicz W, Kryštufek B, Reijnders PJH, Spitzenberger F, Stubbe M, Thissen JBM, Vohralík V, Zima J. 1999. The atlas of European mammals. London: Academic Press.

Murphy RW. 1993. The phylogenetic analysis of allozyme data: invalidity of coding alleles by presence/absence and recommended procedures. Biochemical Systematics and Ecology 21: 25-38.

Murphy RW, Doyle KD. 1998. Phylogenetics: frequencies and polymorphic characters in genealogical estimation. Systematic Biology 47: 737-761.

Musser GG, Brothers EM, Carleton MD, Hutterer R. 1996. Taxonomy and distributional records of Oriental and European Apodemus, with a review of the Apodemus-Sylvaemus problem. Bonner Zoologische Beiträge 46: 143-190.

Musser GG, Carleton MD. 1993. Family Muridae. In: Wilson DE, Reeder DAM, eds. Mammal species of the world, 2nd edn. Washington and London: Smithsonian Institution Press. 501-755. 
Nascetti G, Filippucci MG. 1984. Variabilitá e divergenza genetica in popolazioni italiane di. Apodemus sylvaticus e Apodemus flavicollis (Rodentia, Muridae). In: Contoli L, Cristaldi M, Filippucci MG, Tizi L, Vigna-Taglianti A, eds. Recenti acquisizioni sul genere Apodemus in Italia. Bologna: Supplemento alle Ricerche di Biologia della Selvaggina IX, $75-83$.

Nascetti G, Tizi L, Bullini L. 1980. Differenziazione biochimica e variabilitá genetica in due popolazioni di Apodemus sylvaticus e A. flavicollis (Rodentia, Muridae). Accademia Nazionale Dei Lincei, Rendiconti Della Classe Di Scienze F M N Serie VIII. 67: (1-2): 131-136.

Nei M. 1972. Genetic distance between populations. American Naturalist 106: 283-292.

Nei M. 1975. Molecular population genetics and evolution. Amsterdam and Oxford: North-Holland Publishing Co.

Nei M. 1978. Estimation of average heterozygosity and genetic distance from a small number of individuals. Genetics 89: $583-590$

Nevo E, Filippucci MG, Beiles A. 1990. Genetic diversity and its ecological correlates in nature: comparisons between subterranean, fossorial, and aboveground small mammals. In: Nevo E, Reig OA, eds. Evolution of subterranean mammals at the organismal and molecular levels. New York: Wiley-Liss, 347-366.

Niethammer J. 1969. Zur Frage der Introgression bei den Waldmäusen Apodemus sylvaticus und Apodemus flavicollis (Mamm., Rod.). Zeitschrift für Zoologische Systematik und Evolutionsforschung 7: 77-127.

Niethammer J. 1978. Apodemus mystacinus (Danford and Alston, 1877) - Felsenmaus. Apodemus flavicollis (Melchior, 1834) - Gelbhalsmaus. Apodemus sylvaticus (Linnaeus, 1758 ) - Waldmaus. In: Niethammer J, Krapp F, eds. Handbuch der Säugetiere Europas. Wiesbaden: Akademische Verlagsgesselschaft, 306-358.

Orlov VN, Bulatova NSh, Nadjafova RS, Kozlovsky AI. 1996. Evolutionary classification of European wood mice of the subgenus Sylvaemus based on allozyme and chromosome data. Bonner Zoologische Beiträge 46: 191-202.

Rietschel S, Storch G. 1974. Außgewöhlich erhaltene Waldmäuse (Apodemus atavus Heller, 1936) aus dem ober-Pliozän von Willershausen am Harz. Senkenbergiana Lethaea 54: 491-519.

Rohlf FL. 1997. NTSYS-pc: Numerical Taxonomy and Multivariate Analysis System, version 2.00. Setauket, New York: Exeter Software.

Sage RD, Contreras JR, Roig VG, Patton JL. 1986. Genetic variation in the South American burrowing rodents of the genus Ctenomys (Rodentia, Ctenomyidae). Zeitschrift für Säugetierkunde 51: 158-172.

Saint Girons MC. 1972. Le genre Apodemus Kaup, 1829, au Maroc. Zeitschrift für Säugetierkunde 37: 362-371.

Saint Girons MC, Van Bree PJH. 1963. Recherches sur la répartition et la systématique de Apodemus sylvaticus (Linnaeus, 1758) en Afrique du Nord. Mammalia 26: 478-488.

Saitou N, Nei M. 1987. The neighbor-joining method: a new method for reconstructing phylogenetic relationships. Molecular Biology and Evolution 4: 406-425.
Schnell GD, Selander RK. 1981. Environmental and morphological correlates of genetic variation in mammals. In: Smith MH, Joule J, eds. Mammalian population genetics. Athens: University of Georgia Press, 60-99.

Selander RK. 1976. Genetic variation in natural populations. In: Ayala FJ, ed. Molecular evolution. Sunderland, Massachusetts Sinauer Associates, 21-45.

Serizawa K, Suzuki H, Tsuchiya K. 2000. A phylogenetic view on species radiation in Apodemus inferred from variation of nuclear and mitochondrial genes. Biochemical Genetics 38: 27-40.

Storch G. 1975. Eine Mittelpleistozäne Nager-Fauna von der Insel Chios, Ägäis (Mammalia, Rodentia). Senkenbergiana Biologica 56: 165-189.

Storch G. 1977. Die Ausbreitung der Felsenmaus (Apodemus mystacinus): Zur Problematik der Inselbesiedlung und Tiergeographie der Ägäis. Natur und Museum 107: 174182.

Storch G, Lütt O. 1989. Artstatus der Alpenwaldmaus, Apodemus alpicola Heinrich, 1952. Zeitschrift für Säugetierkunde 54: 337-346.

Suzuki H, Tsuchiya K, Sakaizumi M, Wakana S, Gotoh O, Saitou N, Moriwaki K, Sakurai S. 1990. Differentiation of restriction sites in ribosomal DNA in the genus Apodemus. Biochemical Genetics 28: 137-149.

Suzuki H, Tsuchiya K, Takezaki N. 2000. A molecular phylogenetic framework for the Ryuku endemic rodents Tokudaia osimensis and Diplothrix legata. Molecular Phylogenetics and Evolution 15: 15-24.

Swofford DL, Berlocher SH. 1987. Inferring evolutionary trees from gene frequency data under the principle of maximum parsimony. Systematic Zoology 36: 293-325.

Swofford DL, Olsen GJ, Waddel PJ, Hillis DM. 1996. Phylogenetic inference. In: Hillis DM, Moritz C, Mable BK, eds. Molecular systematics, 2nd edn. Sunderland, Massachusetts: Sinauer Associates, Inc., 407-514.

Swofford DL, Selander RK. 1981. BIOSYS-1: a FORTRAN program for the comprehensive analysis of electrophoretic data in population genetics and systematics. Journal of Heredity 72: 281-283.

Tchernov E. 1979. Polymorphism, size trends and pleistocene paleoclimatic response of the subgenus Sylvaemus (Mammalia, Rodentia) in Israel. Israel Journal of Zoology 28: 131-159.

Vigne JD. 1990. Biogeographical history of the mammals on Corsica (and Sardinia) since the final Pleistocene. Atti Dei Convegni Lincei. Biogeographical Aspects of Insularity. Rome: Accademia Nazionale dei Lincei, 369-392.

Vogel P, Maddalena T, Mabile A, Paquet G. 1991. Confirmation biochimique du status spécifique du mulot alpestre Apodemus alpicola Heinrich, 1952 (Mammalia, Rodentia). Bulletin de Société vaudoise Des Sciences naturelles 80: 471-481.

Vorontsov NN, Boyeskorov GG, Mezhzherin SV, Lyapunova EA, Kandaurov AS. 1992. Systematics of the Caucasian wood mice of the subgenus Sylvaemus (Mammalia, Rodentia, Apodemus). Zoologicheskii Zhurnal 71: 119-131 (in Russian, with English summary). 
Witte G. 1964. Introgression bei Apodemus flavicollis und A. sylvaticus. Biometrische Untersuchungen an ApodemusPopulationen des Monte Gargano (Süd-Italien). Bonner Zoologische Beiträge 5: 159-177.

Wright S. 1943. Isolation by distance. Genetics 28: 114-138.

Wright S. 1965. The interpretation of population structure by F-statistics with special regard to systems of mating. Evolution 19: 395-420.

Wright S. 1978. Evolution and the genetics of populations, Vol. 4. Variability within and among natural populations. Chicago: University of Chicago Press.
Zagorodnyuk IV, Boyeskorov GG, Zykov OE. 1997. Variation and taxonomic status of the steppe forms of genus $S y l$ vaemus 'sylvaticus' (falzfeini - fulvipectus - hermonensis arianus). Vestnik Zoologii 31: 37-56 (in Russian, with English abstract).

Zimmermann K. 1962. Die Untergattungen der Gattung Apodemus Kaup. Bonner Zoologische Beiträge 13: 198208.

Zimmermann EG, Kilpatrick CW, Hartl BJ. 1978. The genetics of speciation in the rodent genus Peromyscus. Evolution 32: 565-579.

\section{APPENDIX 1}

LIST OF COLLECTING SITES, POPULATION ACRONYMS, AND NUMBER OF SPECIMENS ANALYSED.

See also Macholán et al. (2001a) for more details on Turkish localities.

Species/Localities

Code

$N$

A. sylvaticus

Morocco:

Forêt de la Mamora (2), Bab Berred (5),

SMOR

Algeria:

Ketama (7), Ouezzane (2),

Mt. Zerhoun (1), Cap Spartel (1)

Tunisia:

Akfadou (5), Costantina (1),

SALG

Spain:

El Milia (1), Mt. Edough (2)

Aindram (6), Zaguan (3)

STUN

Ibiza

Posada

SIBI

SPOS

Alcoy

SALC

Fabian

SFAB

Torla

France:

Ré

Cap Lardier

STOR

SRE

Port Cros

SCPL

SPCR

Porquerolles

SPOR

SBAN

Banyuls sur Mer

SCOR

Belgium:

Corsica

SLIE

Namur

SNAM

Switzerland:

Zurich

SZUR

Germany:

Soest

Bielefeld

SSOE

SBIE

England:

Horton

SHOR

Sicily: Palermo (2),

SSIC

Italy:

Madonie Mts. (26), Mt. Etna (8)

Mt. Aspromonte, Calabria

SASP

Mt. Pollino, Basilicata

SPOL

Gargano, Apulia

SGAR

Penne, Abruzzo

SPEN

Lepini Mts., Latium

SLEP

Colleferro, Latium

SCLF

Rome, Latium

SROM

S. Polo dei Cavalieri, Latium

SSPC

Mt. Fogliano, Latium

SMFO

Tolfa Mts., Latium

STOL

Tarquinia, Latium

STRQ

Burano, Tuscany

SBUR

Grosseto, Tuscany

SGRO

18

9

9

1 
Species/Localities

Code

Elba Island, Tuscany

SELB

P. Tricoli, Sardinia

SSAR

St. Pierre, Valle d'Aosta

SVAO

Yugoslavia:

Šušara, Vojvodina

SSUS

Bistra Mts.

Macedoni
Greece:

Goumenissa, Macedonia

SBIS

Ilis, Peloponnesus

Turkey:

Çaycuma, Zonguldak

SGOU

SILI

SCAY

$N$

A. flavicollis Italy:

Mt. Aspromonte, Calabria

FASP

FGAR

Gargano, Apulia

FPEN

Penne, Abruzzo

FLEP

Lepini Mts., Latium

Tolfa Mts., Latium

FTOL

Mt. Fogliano, Latium

FMFO

Rieti, Latium

Tarvisio, Friuli

Austria:

Germany:

Sweden:

Yugoslavia:

Macedonia:

Greece:

Thüringerberg, Vorarlberg

FRIE

FTAR

Bielefeld, Wuppertal, North Rhine

FVOR

Uppsala

Šušaara, Vojvodina

Mt. Pelister

Goumenissa, Macedonia

Mt. Verno, Epirus

Turkey:

Strandzha Mts., Kirklareli, Thrace

FBIE

FUPS

FSUS

FPEL

FGOU

FMVE

FIST

Safranbolu, Zonguldak

Yenice, Zonguldak

Göksuyu river, Kütahya

Eğirdir, Isparta

Datca, Marmaris

Ölüdeniz, Fethiye, Muðla

Güzyurdu, Gümüshane

Damar, Artvin

Armenia:

Echmiadzin, Yerevan

FSAF

FYEN

FKUT

FEGR

FDAT

FOLD

FGUZ

FDAM

FYER

Gholaman, Khorram Abad, Lorestan

FGHO

Golan Heights

Israel:

Tel. Dan

FGOL

FTLD

FUGA

FMCA

$$
\begin{array}{r}
51 \\
36 \\
9 \\
70 \\
24 \\
9 \\
6 \\
25 \\
12
\end{array}
$$

Mt. Carmel

UMOR 12

Vrbovec, Znojmo, S. Moravia

USUS

UUDG

Uludağ Mts., Bursa

Bolu

UBOL

Lake Abant, Bolu

UABA

Hanyatak, Sakarya

UHAN

Yenice, Zonguldak

UYEN

Safranbolu, Zonguldak

USAF

UGUZ

Yalnizçam Pass, Artvin

UYAL

Bağdaşan, Kars

UBGD

Seyfe, Amasya

USFE

Damar, Artvin

UDAM

UKBC

Sumelas, Trabzon

USUM 
A. cf. hyrcanicus Iran:

\section{A. hermonensis} Israel:

Turkey:

Iran:

A. m. mystacinus Turkey:

Israel:

A. m. epimelas

Macedonia:

A. alpicola

Italy:

Collardente, Liguria

Entreves, Valle d'Aosta

Safranbolu, Zonguldak

Ciglikara, Antalya

Ölüdeniz, Fethiye, Muğla

Mt. Hermon

Golan Heights

Upper Galilee

Mt. Carmel

Hirbet Se'Adim, Judea Mts.

Galičica Mts.

MGAL

1

S. Eulalia, Treviso, Venetia Šušara, Vojvodina

ASLM 6

NOWK

HHER

HUDG

HABA

HYEN

HSAF

HKUT

HCIG

HGUZ

HYAL

HSFE

HDAM

HSBS

HHAK

HDOG

HBUR

HGHO

HBHS

HABS

HSIV

HVAL

MSAF

MCIG

MOLD

MHER

MGOL

MUGA

MMCA

MJUD

ALIG

AVAO

11

A. agrarius

Italy:

Yugoslavia:

A. peninsulae

Russia:
AGIT

AGYU

5

4 


\section{APPENDIX 2}

ALLELIC FREQUENCIES IN APODEMUS SPECIES

\begin{tabular}{|c|c|c|c|c|c|c|c|c|c|c|}
\hline Locus & SYL & FLA & ALP & HER & URA & HYR & MYS & EPI & PEN & AGR \\
\hline \multicolumn{11}{|l|}{ Adh } \\
\hline 100 & 0.90 & - & 1.00 & - & 0.96 & - & - & & & \\
\hline 98 & 0.07 & - & - & - & - & - & - & & & \\
\hline 94 & 0.03 & - & - & 0.03 & 0.04 & - & - & & & \\
\hline 92 & - & 1.00 & - & 0.93 & - & - & - & & & \\
\hline 90 & - & - & - & - & - & - & 1.00 & & & \\
\hline 85 & - & - & - & - & - & 1.00 & - & & & \\
\hline 83 & - & - & - & 0.04 & - & - & - & & & \\
\hline \multicolumn{11}{|l|}{$\alpha G p d h$} \\
\hline 110 & - & - & - & - & - & - & 1.00 & 1.00 & - & - \\
\hline 108 & 0.04 & - & - & - & - & - & - & - & - & 1.00 \\
\hline 106 & - & - & - & - & 0.93 & 1.00 & - & - & 1.00 & - \\
\hline 104 & 0.07 & - & - & - & - & - & - & - & - & - \\
\hline 102 & - & 1.00 & 1.00 & 0.99 & 0.04 & - & - & - & - & - \\
\hline 100 & 0.89 & - & - & - & - & - & - & - & - & - \\
\hline 97 & - & - & - & - & 0.03 & - & - & - & - & - \\
\hline 93 & - & - & - & 0.01 & - & - & - & - & - & - \\
\hline \multicolumn{11}{|l|}{$S d h$} \\
\hline 105 & - & - & - & - & - & - & 1.00 & 1.00 & - & - \\
\hline 100 & 1.00 & 1.00 & 1.00 & 1.00 & 1.00 & 1.00 & - & - & - & - \\
\hline 95 & - & - & - & - & - & - & - & - & 1.00 & 1.00 \\
\hline \multicolumn{11}{|l|}{$L d h-1$} \\
\hline 108 & - & - & - & - & - & - & 0.02 & - & - & - \\
\hline 104 & - & 1.00 & 1.00 & 1.00 & 1.00 & 1.00 & 0.98 & - & - & - \\
\hline 100 & 0.98 & - & - & - & - & - & - & - & - & - \\
\hline 90 & 0.02 & - & - & - & - & - & - & - & 1.00 & 1.00 \\
\hline 85 & - & - & - & - & - & - & - & 1.00 & - & - \\
\hline \multicolumn{11}{|l|}{$L d h-2$} \\
\hline 115 & - & - & - & - & - & - & - & 1.00 & - & - \\
\hline 100 & 1.00 & 1.00 & 1.00 & 1.00 & 1.00 & 1.00 & 1.00 & - & - & - \\
\hline 97 & - & - & - & - & - & - & - & - & 1.00 & 1.00 \\
\hline \multicolumn{11}{|l|}{$M d h-1$} \\
\hline 100 & 1.00 & 1.00 & 1.00 & 1.00 & 1.00 & 1.00 & 1.00 & 1.00 & - & - \\
\hline 93 & - & - & - & - & - & - & - & - & 1.00 & 1.00 \\
\hline \multicolumn{11}{|l|}{$M e-1$} \\
\hline 120 & - & - & - & - & - & - & 0.07 & - & - & - \\
\hline 115 & - & - & - & - & - & - & 0.92 & - & - & - \\
\hline 112 & - & - & - & - & - & - & 0.01 & 1.00 & - & 0.11 \\
\hline 110 & - & 0.01 & 0.19 & - & - & - & - & - & - & - \\
\hline 108 & - & - & - & - & - & - & - & - & - & 0.89 \\
\hline 105 & 0.17 & 0.23 & 0.45 & 0.15 & 0.26 & - & - & - & - & - \\
\hline 100 & 0.83 & 0.72 & 0.33 & 0.85 & 0.74 & 0.19 & - & - & 1.00 & - \\
\hline 93 & - & 0.04 & 0.03 & - & - & 0.81 & - & - & - & - \\
\hline \multicolumn{11}{|l|}{$\mathrm{Me}-2$} \\
\hline 103 & - & - & - & - & - & - & - & 1.00 & - & - \\
\hline 100 & 1.00 & - & - & - & - & - & - & - & - & - \\
\hline 98 & - & - & - & 0.04 & 0.01 & - & - & - & - & - \\
\hline 97 & - & - & - & - & - & - & 0.08 & - & - & - \\
\hline 94 & - & 0.93 & 0.92 & 0.96 & 0.98 & 1.00 & 0.92 & - & - & - \\
\hline 88 & - & 0.07 & 0.08 & - & 0.01 & - & - & - & - & - \\
\hline 84 & - & - & - & - & - & - & - & - & - & 1.00 \\
\hline 80 & - & - & - & - & - & - & - & - & 1.00 & - \\
\hline
\end{tabular}


Idh-1

115

108

104

100

90

Idh-2

100

96

6Pgdh

115

112

110

108

100

98

92

G6pd

104

100

96

92

G3pd

105

100

Ipo-1

115

110

100

82

Ipo-2

105

100

97

Np

105

104

103

100

97

95

90

Got-1

106

102

100

97

Got-2

105

100

Hk-1

104

100

$\mathrm{Hk}-2$

105

100

$\begin{array}{llll}- & - & - & - \\ 0.02 & 0.98 & 0.03 & 1.00 \\ - & - & - & - \\ 0.98 & 0.01 & 0.97 & - \\ - & 0.01 & - & -\end{array}$

$1.00 \quad 1.00$

1.00

1.00

1.00

1.00

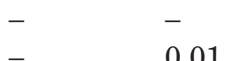

$\begin{array}{ll}- & - \\ - & -\end{array}$

$-$

$-$

- 01

$-$

0.01

0.68

$-$

$-$

0.97

$-$

0.31

0.03

$\begin{array}{ll}- & - \\ 1.00 & 1.00\end{array}$

$-$

1.00

$-$

$-$

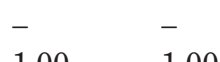

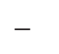

1.00

$-$

1.00

0.01

0.99

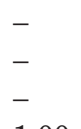

1.00

1.00

1.00

$\begin{array}{ll}- & - \\ 1.00 & 1.00\end{array}$

$-$

-
-
1.00

-
-
-

-
1.00
-

-
-
-
-
-
1.00

-
-
-
-
-
-
1.00

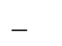

$0.02 \quad 0.08$

0.02
-
0.98

$-$

$-$

$$
0.02
$$$$
0.98
$$

$0.04-$

$\overline{0} .96 \quad \overline{1.00}$

$-$

$-$

$-$

$-$

$-$

$-$

- $\quad-$

$-$

1.00

1.00

${ }_{1.00}$

$-$
-
-
-
1.00

1.00

1.00

1.00

0.94

0.06

0.33

1.00

$-$

$-$

0.92

$-$

0.06

$-$

$-$

$-$

0.99

0.01

$-$

$-$

1.00

1.00

$\begin{array}{llll}- & - & - & 1.00\end{array}$

$\begin{array}{lll}- & - & - \\ - & - & -\end{array}$

1.00

1.00

1.00

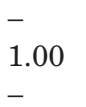

$-$

-
-
1.00

1.00

$-$

1.00

$-$

$-$

$-$

$-$

$-$

$\begin{array}{llll}- & - & - & 0.06 \\ 0.15 & - & - & - \\ - & - & - & - \\ 0.85 & 1.00 & 1.00 & 0.94\end{array}$

$\begin{array}{llll}- & - & - & \end{array}$

$\begin{array}{lll}1.00 & 1.00 & 1.00\end{array}$

$\begin{array}{llll}0.02 & - & 1.00 & 1.00\end{array}$

$0.98 \quad 1.00$

$-$

$-$

1.00

1.00 


\begin{tabular}{|c|c|c|c|c|c|c|c|c|c|c|}
\hline Locus & SYL & FLA & ALP & HER & URA & HYR & MYS & EPI & PEN & AGR \\
\hline \multicolumn{11}{|l|}{$C k$} \\
\hline 105 & - & - & - & - & - & - & 0.01 & - & - & - \\
\hline 100 & 1.00 & 1.00 & 1.00 & 1.00 & 1.00 & 1.00 & 0.99 & 1.00 & 1.00 & 1.00 \\
\hline \multicolumn{11}{|l|}{$A d k$} \\
\hline 103 & 0.01 & - & - & - & - & - & - & - & - & - \\
\hline 100 & 0.99 & 1.00 & 1.00 & 1.00 & 1.00 & 1.00 & 1.00 & 1.00 & 1.00 & 1.00 \\
\hline \multicolumn{11}{|l|}{ Pgm-1 } \\
\hline 110 & 0.02 & - & - & - & - & - & - & - & - & \\
\hline 103 & 0.02 & 0.03 & - & - & - & - & 0.04 & 1.00 & - & \\
\hline 100 & 0.94 & 0.96 & 1.00 & 0.99 & 1.00 & 1.00 & 0.96 & - & - & \\
\hline 95 & 0.02 & 0.01 & - & 0.01 & - & - & - & - & 0.94 & \\
\hline 90 & - & - & - & - & - & - & - & - & 0.06 & \\
\hline \multicolumn{11}{|l|}{ Pgm-2 } \\
\hline 104 & 0.01 & 0.04 & - & - & 0.01 & - & 0.04 & - & - & - \\
\hline 100 & 0.99 & 0.96 & 1.00 & 1.00 & 0.99 & 1.00 & 0.96 & 1.00 & 1.00 & 0.77 \\
\hline 90 & - & - & - & - & - & - & - & - & - & 0.23 \\
\hline \multicolumn{11}{|l|}{ Est-1 } \\
\hline 106 & - & - & - & - & - & - & - & - & 1.00 & 0.61 \\
\hline 103 & - & - & - & 0.04 & 0.11 & - & 0.06 & - & - & - \\
\hline 100 & 1.00 & 1.00 & 1.00 & 0.96 & 0.87 & 1.00 & 0.88 & - & - & 0.39 \\
\hline 95 & - & - & - & - & 0.02 & - & 0.06 & 1.00 & - & - \\
\hline \multicolumn{11}{|l|}{ Est-2 } \\
\hline 106 & - & - & - & - & - & - & - & - & 1.00 & - \\
\hline 104 & - & - & - & - & - & - & 0.06 & 1.00 & - & - \\
\hline 100 & 1.00 & 0.98 & 0.91 & 0.81 & - & 1.00 & 0.77 & - & - & 1.00 \\
\hline 98 & - & - & - & - & 0.17 & - & 0.17 & - & - & - \\
\hline 95 & - & 0.02 & 0.09 & 0.19 & 0.83 & - & - & - & - & - \\
\hline \multicolumn{11}{|l|}{ Est-3 } \\
\hline 110 & - & - & - & - & 0.01 & 0.06 & 0.02 & - & - & - \\
\hline 108 & - & - & - & - & - & - & - & - & - & 1.00 \\
\hline 105 & 0.04 & 0.01 & - & - & - & - & 0.82 & 1.00 & 1.00 & - \\
\hline 100 & 0.87 & 0.68 & 1.00 & 0.99 & 0.99 & 0.94 & 0.16 & - & - & - \\
\hline 95 & 0.09 & 0.31 & - & 0.01 & - & - & - & - & - & - \\
\hline \multicolumn{11}{|l|}{ Acph } \\
\hline 105 & - & - & - & - & - & 0.04 & 1.00 & & & \\
\hline 100 & 1.00 & 1.00 & 1.00 & 1.00 & 1.00 & 0.96 & - & & & \\
\hline \multicolumn{11}{|l|}{ Pep-1 } \\
\hline 109 & - & - & - & - & 0.01 & - & - & - & - & - \\
\hline 105 & - & - & - & 0.02 & 0.99 & 1.00 & 1.00 & - & 1.00 & - \\
\hline 100 & 1.00 & 0.27 & - & 0.98 & - & - & - & 1.00 & - & 1.00 \\
\hline 94 & - & 0.73 & 1.00 & - & - & - & - & - & - & - \\
\hline \multicolumn{11}{|l|}{ Рep-2 } \\
\hline 106 & - & - & - & - & - & - & - & - & 1.00 & - \\
\hline 103 & - & - & - & - & - & - & - & 1.00 & - & - \\
\hline 100 & 1.00 & 1.00 & 1.00 & - & 0.99 & 1.00 & - & - & - & - \\
\hline 96 & - & - & - & 1.00 & - & - & - & - & - & 1.00 \\
\hline 90 & - & - & - & - & 0.01 & - & 1.00 & - & - & - \\
\hline \multicolumn{11}{|l|}{ Рер-3 } \\
\hline 100 & 1.00 & 0.95 & 1.00 & 1.00 & 0.99 & 1.00 & - & - & & \\
\hline 97 & - & 0.05 & - & - & 0.01 & - & 1.00 & 1.00 & & \\
\hline \multicolumn{11}{|l|}{$A d a$} \\
\hline 125 & - & - & - & - & - & - & - & - & - & 1.00 \\
\hline 120 & - & - & - & - & - & - & 0.05 & - & - & - \\
\hline 115 & - & - & - & 0.07 & - & - & - & - & - & - \\
\hline
\end{tabular}




\begin{tabular}{|c|c|c|c|c|c|c|c|c|c|c|}
\hline 113 & - & - & - & - & - & 0.19 & 0.93 & 1.00 & 1.00 & - \\
\hline 108 & 0.05 & 0.07 & 0.08 & 0.07 & 0.10 & - & - & - & - & - \\
\hline 105 & - & - & - & - & - & 0.82 & - & - & - & - \\
\hline 100 & 0.91 & 0.90 & 0.92 & 0.86 & 0.88 & - & - & - & - & - \\
\hline 95 & 0.02 & 0.02 & - & - & - & - & - & - & - & - \\
\hline 90 & 0.01 & - & - & - & - & - & 0.02 & - & - & - \\
\hline 85 & 0.01 & 0.01 & - & - & 0.02 & - & - & - & - & - \\
\hline \multicolumn{11}{|l|}{ Fum } \\
\hline 103 & - & - & - & - & - & - & - & - & 1.00 & 1.00 \\
\hline 100 & 1.00 & 1.00 & 1.00 & 1.00 & 1.00 & 1.00 & 1.00 & 1.00 & - & - \\
\hline \multicolumn{11}{|l|}{ Aldo } \\
\hline 105 & - & - & - & - & - & - & - & - & 1.00 & - \\
\hline 100 & 1.00 & 1.00 & 1.00 & 1.00 & 1.00 & 1.00 & 1.00 & 1.00 & - & - \\
\hline 95 & - & - & - & - & - & - & - & - & - & 1.00 \\
\hline \multicolumn{11}{|l|}{$M p i$} \\
\hline 103 & 0.01 & 0.02 & - & - & - & - & - & - & - & - \\
\hline 100 & 0.97 & 0.98 & 1.00 & 1.00 & 0.99 & 1.00 & 0.14 & - & - & - \\
\hline 97 & - & - & - & - & - & - & 0.86 & - & - & - \\
\hline 95 & 0.02 & - & - & - & 0.01 & - & - & - & 0.25 & - \\
\hline 93 & - & - & - & - & - & - & - & 1.00 & - & - \\
\hline 90 & - & - & - & - & - & - & - & - & 0.75 & 1.00 \\
\hline \multicolumn{11}{|l|}{ Pgi } \\
\hline 104 & - & 0.01 & - & - & 0.01 & - & - & - & - & - \\
\hline 100 & 0.99 & 0.91 & 1.00 & 0.73 & 0.96 & 1.00 & 1.00 & 1.00 & 1.00 & - \\
\hline 96 & 0.01 & 0.06 & - & 0.27 & 0.03 & - & - & - & - & - \\
\hline 94 & - & - & - & - & - & - & - & - & - & 1.00 \\
\hline 90 & - & 0.02 & - & - & - & - & - & - & - & - \\
\hline
\end{tabular}

